\title{
Forest understorey communities respond strongly to light in interaction with forest structure, but not to microclimate
} warming

\section{Karen De Pauw ${ }^{1}$ (D) Pieter Sanczuk $^{1}$ (D), Camille Meeussen ${ }^{1}$ (D), Leen Depauw1 ${ }^{1}$ (D) Emiel De Lombaerde ${ }^{1}$ (D), Sanne Govaert $^{1}$ (D), Thomas Vanneste ${ }^{1}$ (D) Jörg Brunet ${ }^{2}$ (D), Sara A. O. Cousins ${ }^{3}$ (D) Cristina Gasperini ${ }^{4}$ (D), Per-Ola Hedwall $^{2}$ (D), Giovanni Iacopetti ${ }^{4}$ (D) , Jonathan Lenoir ${ }^{5}$ (D) Jan Plue ${ }^{6}$ (D), Federico Selvi ${ }^{4}$ (D), Fabien Spicher ${ }^{5}$ (D), Jaime Uria-Diez ${ }^{2}$ (D), Kris Verheyen ${ }^{1}$ (D), Pieter Vangansbeke ${ }^{1}$ (D) and Pieter De Frenne ${ }^{1}$}

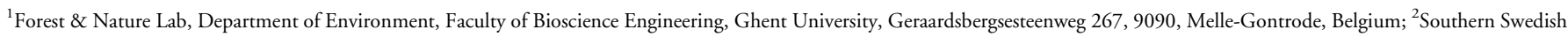
Forest Research Centre, Swedish University of Agricultural Sciences, Box 190, 234 22, Lomma, Sweden; ${ }^{3}$ Landscapes, Environment and Geomatics, Department of Physical Geography, Stockholm University, Svante Arrhenius väg 8, 106 91, Stockholm, Sweden; ${ }^{4}$ Department of Agriculture, Food, Environment and Forestry, University of Florence, P. le Cascine 28, 50144, Florence, Italy; ${ }^{5}$ UMR CNRS 7058 'Ecologie et Dynamique des Systèmes Anthropisés' (EDYSAN), Université de Picardie Jules Verne, 1 Rue des Louvels, 80000, Amiens, France; ${ }^{6}$ IVL Swedish Environmental Institute, Valhallavägen 81, 114 28, Stockholm, Sweden

Author for correspondence: Karen De Pauw

Email: Karen.depauw@UGent.be

Received: 16 June 2021

Accepted: 1 October 2021

New Phytologist (2021)

doi: $10.1111 /$ nph.17803

Key words: climate change experiment, forest specialists, forest structure, forest understorey, functional traits, generalists, light, microclimate.

\section{Summary}

- Forests harbour large spatiotemporal heterogeneity in canopy structure. This variation drives the microclimate and light availability at the forest floor. So far, we do not know how light availability and sub-canopy temperature interactively mediate the impact of macroclimate warming on understorey communities.

- We therefore assessed the functional response of understorey plant communities to warming and light addition in a full factorial experiment installed in temperate deciduous forests across Europe along natural microclimate, light and macroclimate gradients. Furthermore, we related these functional responses to the species' life-history syndromes and thermal niches.

- We found no significant community responses to the warming treatment. The light treatment, however, had a stronger impact on communities, mainly due to responses by fastcolonizing generalists and not by slow-colonizing forest specialists. The forest structure strongly mediated the response to light addition and also had a clear impact on functional traits and total plant cover.

- The effects of short-term experimental warming were small and suggest a time-lag in the response of understorey species to climate change. Canopy disturbance, for instance due to drought, pests or logging, has a strong and immediate impact and particularly favours generalists in the understorey in structurally complex forests.

\section{Introduction}

Forest plants growing in the understorey experience environmental conditions that differ critically from open habitats (Valladares et al., 2016; De Frenne et al., 2021). In dense forests, understorey plants are confronted with deep shade. In summer, forest floor light levels generally range between $0.7 \%$ and $7 \%$ of the incident light above the canopy (Neufeld \& Young, 2014). Such low light levels affect the growth and survival of understorey plants (Whigham, 2004; Plue et al., 2013; Neufeld \& Young, 2014) and strongly determines understorey community composition, functional responses and biodiversity in temperate forests (Marialigeti et al., 2016; Depauw et al., 2019). Light availability at the forest floor varies with canopy cover, structural complexity and tree species identity (Angelini et al., 2015), and is intimately linked with the forest microclimate since the attenuation of solar radiation through the canopy is one of the main drivers of microclimate buffering (De Frenne et al., 2021). Forest microclimates buffer free-air temperatures (referred to as 'macroclimate') (De Frenne et al., 2019), providing cooler maximum, warmer minimum temperatures and reduced temperature variation (De Frenne et al., 2019; Zellweger et al., 2019). Not only shading but also evapotranspiration, air-mixing from wind, landscape structure, topography and macroclimate determine local forest microclimates (Bramer et al., 2018; Davis et al., 2019; De Frenne et al., 2019). Forest microclimates also have a strong influence on biodiversity and species composition as microclimate gradients affect species composition (De Frenne et al., 2021), both vertically (Scheffers et al., 2013; De Smedt et al., 2019) and horizontally (Tinya et al., 2019). 
In the light of climate change, microclimate buffering plays an important role through the creation of local microrefugia for understorey species that cannot cope with warming or drought (Lenoir et al., 2017; Zellweger et al., 2020; Ellis \& Eaton, 2021; Williamson et al., 2021). In these microrefugia, conditions are more stable which can raise species' chance on persistence and extend their time to adapt (by for example acclimation (Wasof $e t$ al., 2013)) or to track climate change by shifting its distribution range (e.g. poleward or upward in elevation (Lenoir et al., 2008; Lenoir \& Svenning, 2015)). Especially for species with limited dispersal capabilities such as many forest plant specialists (Verheyen et al., 2003; Matlack, 2005; Svenning et al., 2008; De Frenne et al., 2013b), their ability to track climate change remains questionable under the current rate of warming, notably in the context of forest fragmentation (Lenoir et al., 2020).

Forest canopies are spatiotemporally extremely heterogeneous, resulting in significant differences in light availability and microclimate buffering. Structural heterogeneity in forest canopies is caused by natural agents of disturbances, such as insects, pathogens, wildfires and wind, but this varies with the disturbance's level and type (Swanson et al., 2011; Thers et al., 2019). Furthermore, management strongly impacts the overstorey through thinning, clear-cuts, and selection cuts. Different management strategies can therefore result in differences in microclimate buffering, that vary spatially within and among stands, and across timescales of seasons to decades (Ehbrecht et al., 2017; Kovács et al., 2020). Furthermore, uneven-aged multi-species stands and old-growth forests tend to have a higher structural complexity and more buffered microclimate than even-aged or monospecific stands (Frey et al., 2016; Ehbrecht et al., 2017, 2019). In the future, forests might face higher tree mortality due to climate change, extreme weather events and increasing pest outbreaks (Stott, 2016; Jactel et al., 2019; Grossiord et al., 2020; Senf \& Seidl, 2020), opening up the canopy (Jump et al., 2017; Brodribb et al., 2020), increasing the light availability and disrupting the buffering microclimate. During the last three decades, disturbed forest patches in Europe were on average 1.09 ha, occurred with an annual average frequency of one disturbance patch per $2.56 \mathrm{~km}^{2}$ forest, and this frequency significantly increased over time (Senf \& Seidl, 2020). Such disturbances can result in light increases of $+227 \%$ to $+387 \%$ relative to undisturbed forest patches, and each $10 \%$ light increase raised daily microclimatic temperature variation with $0.11^{\circ} \mathrm{C}$ (Thom et al., 2020).

Importantly, the forest microclimate and light availability also vary with distance to the forest edge (Matlack, 1993; Gehlhausen et al., 2000). Typically, forest edges receive more light and higher wind speeds, resulting in drier soil conditions and less microclimatic buffering (Matlack, 1993; Chen et al., 1999; Gehlhausen et al., 2000). Reported distances of edge effects vary strongly but range generally between 8 and $40 \mathrm{~m}$ for light conditions (Matlack, 1993; Gehlhausen et al., 2000; Honnay et al., 2002) and between 5 and $40 \mathrm{~m}$ for air temperatures (Saunders et al., 1999; Davies Colley et al., 2000; Schmidt et al., 2019). In Europe, $40 \%$ of the forest area is situated within $100 \mathrm{~m}$ from a forest edge (Estreguil et al., 2012).
Differences in canopy structure or edge vs interior conditions strongly determine both light availability and the forest microclimate, yet warming experiments in forests hitherto did not consider these factors (Farnsworth et al., 1995; Kaarlejärvi et al., 2012; Hedwall et al., 2015; Blondeel et al., 2020b; Govaert et al., 2021). So far, it is unclear how below-canopy warming affects forest plants in different microclimates and light conditions. Furthermore, interactive effects between warming and additional light are expected (De Frenne et al., 2015; Dietz et al., 2020).

It is clear that species' responses to warming differ and numerous studies use the mean temperature across a species' distribution range as a proxy for its thermal tolerance (Becker-Scarpitta et al., 2019; Dietz et al., 2020; Feeley et al., 2020), hereafter referred to as thermal niche optimum (Vangansbeke et al., 2021). Similarly, understorey plants differ in their response to light (Tinya et al., 2019). Plants respond to changing environmental conditions, such as light and temperature, with changes in key functional traits, such as plant height and specific leaf area (SLA) (Poorter et al., 2009; Blondeel et al., 2020a). These functional traits reflect each plants' growth, performance and function since plant height is clearly linked to a species' competitive ability, whereas SLA gives more insight in the plant's resource acquisition strategy (Westoby, 1998; Westoby \& Wright, 2006; Diaz et al., 2016).

Additionally, plants differ in life-history traits and their association with past land-use and early vs late successional stages. Typical slow-colonizing forest specialists are often associated with ancient forests (defined as forests situated on land that has been continuously covered by forest for centuries) (Graae \& Sunde, 2000; Verheyen et al., 2003; De Frenne et al., 2011), seen as late-successional species and regularly characterized as smaller plants with heavy seeds and a more resource conservative strategy (Graae \& Sunde, 2000; Verheyen et al., 2003; Blondeel et al., 2019). Contrarily, generalists are often found abundantly at forest edges, preferring conditions with more light for rapid growth (Honnay et al., 2002; Govaert et al., 2020) and they tend to occur in more recent and post-agricultural forests as fastcolonizing, more early-successional species. These generalists are often taller and have a more acquisitive resource strategy (Verheyen et al., 2003; Blondeel et al., 2019). The occurrence of species in ancient vs recent forests, quantified as the colonizing capacity index (CCI) (Verheyen et al., 2003), is linked to the specialist-generalist spectrum, secondary succession and species' life-history syndrome, which comprises several functional lifehistory traits.

Here we use a large-scale state-of-the-art warming and light experiment to assess the response of understorey plant communities to increased temperature and light levels in the field. The experiment involves two climatic gradients operating at different spatial extents and resolutions: a macroclimate gradient from southern (Italy) to northern Europe (Sweden) and local microclimate gradients through forest structure and distance to edge difference. We use a full-factorial design to disentangle responses to light and warming, which are both strongly affected by the overstorey and hard to separate in observational studies. In total, the experiment consisted of 6912 individuals of 12 species. Several 
species were transplanted beyond their northern and/or close to their southern range edge (Supporting Information Fig. S1). Plants were transplanted in 432 synthetic communities, each containing several individuals from four species varying in lifehistory syndrome and thermal tolerance. During two growing seasons we performed measurements of intraspecific functional traits (plant height and SLA), as well as species' plant cover (as proxy for biomass and productivity). We hypothesize that:

(1) Understorey communities respond both functionally (in terms of SLA and plant height) and in terms of total plant cover to the warming treatment, but this response will interact with the light treatment.

(2) Both macroclimate (region) and microclimate (forest structure and distance to the edge) will affect the response of the understorey communities to the warming and light treatments.

(3) Species responses to the light treatment are related to their life-history syndrome, whereas responses to the warming treatment depend on the species' thermal niche optimum.

\section{Materials and Methods}

\section{Study regions}

We used three experimental sites along a $1400 \mathrm{~km}$ wide latitudinal gradient spanning the temperate forest biome: one in southern Europe (Montepaldi near Florence, Italy, $43.67^{\circ} \mathrm{N} 11.14^{\circ} \mathrm{E}$ ); one in central western Europe (Gontrode near Ghent, Belgium, $50.97^{\circ} \mathrm{N} 3.80^{\circ} \mathrm{E}$ ); and one in northern Europe (Simlangsdalen near Halmstad, Sweden, $56.71^{\circ} \mathrm{N} 13.12^{\circ} \mathrm{E}$ ). This latitudinal gradient represents a gradient in macroclimate: the mean annual temperature difference between the experimental sites is $6.9^{\circ} \mathrm{C}$ $\left(14^{\circ} \mathrm{C}\right.$ Italy, $10.2^{\circ} \mathrm{C}$ Belgium, $7.1^{\circ} \mathrm{C}$ Sweden) whereas the annual precipitation is more similar with 861,758 and $902 \mathrm{~mm}$ in Italy, Belgium and Sweden respectively (WorldClim 2, most recent 30year average from 1970 to 2000, resolution of 2.5 arcminutes; Fick \& Hijmans (2017)). We focused on deciduous forests dominated by oak (Quercus sp.) and beech (Fagus sylvatica), as they cover a large part of temperate forests in Europe (Barbati et al., 2014) and support a high number of associated species and rich woodland diversity (Eaton et al., 2016; Mölder et al., 2019). Site-specific dominance of tree species is given in Supporting Information Table S1.

\section{Experimental design}

At each experimental site, we established four locations with contrasting forest structure (shrub, tree layer cover: Table S1) and distance to the forest edge, creating a gradient in microclimate and light availability. We identified forest stands with a simple structure (i.e. one tree layer, shrub cover of maximum $45 \%$, more open canopy) and forest stands with a more complex structure (i.e. presence of shrubs, multiple tree layers, high canopy cover: minimum $15 \%$ in shrub layer and $70 \%$ in tree layer). In each stand we installed the experiment close to $(2 \mathrm{~m}$ from $)$ the forest edge (defined as the hypothetical line of tree stems at the edge) and in the forest interior (at least $50 \mathrm{~m}$ from any edge) (Fig. 1). (a)

(b)

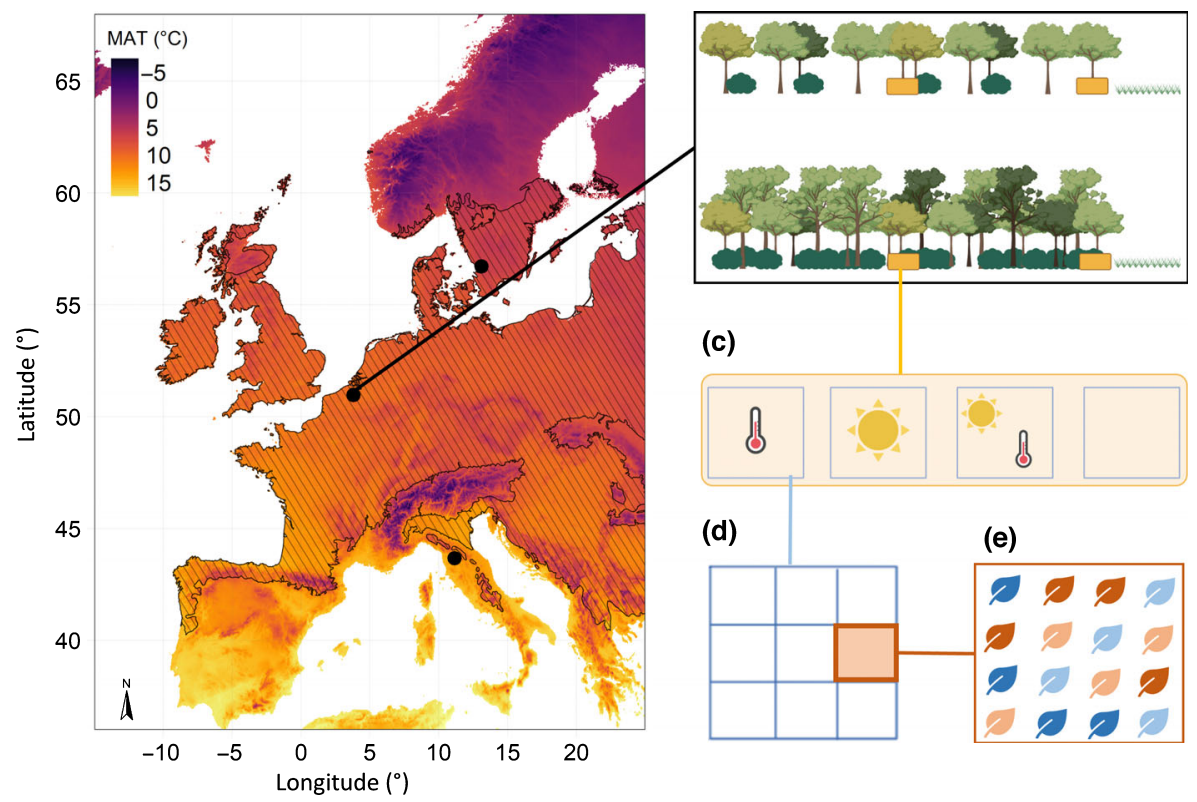

Fig. 1 Experimental design. (a) The studied macroclimatic gradient of mean annual temperature (MAT) (Fick \& Hijmans, 2017) with experimental sites in Sweden, Belgium and Italy. The temperate broadleaf and mixed forest biome (Olson et al., 2001) is outlined and hatched. (b) Each experimental site contains four locations along two microclimatic gradients: two locations in a complex structured forest, two in a simple structured forest and for each forest, one is situated at the forest edge and one in the forest interior. (c) At each experimental location, four treatments are applied to four experimental units: a warming; light; combined warming and light; and a control treatment. (d) Each treatment is applied to an experimental unit consisting of nine mesocosms with understorey plant communities. (e) Each mesocosm contains 16 plants: four individuals of four different species placed in a randomized position. Two species are relatively more warm-adapted (red) and two are relatively more cold-adapted (blue), and within each of these two pairs, one is a generalist and one a forest specialist. 
We used south-facing edges (edge orientation, type of adjacent land: Table S1) to control for the effect of edge orientation on microclimate and community composition (Matlack, 1993; Honnay et al., 2002; Orczewska \& Glista, 2005). Violin plots of microclimate and community response variables grouped by region, structure and plot position are given in Figs S2 and S3.

In every experimental location, we applied four treatments in a full-factorial design: light, warming, light + warming, and a control treatment across the growing season after installation of the experiment, that is from May to end of September in 2019 and from 1 February to beginning of September in 2020. The light was added during daytime (local sunrise to sunset) with two lamps, consisting of two fluorescent tubes each. Above the lamps, we attached plastic shields as rain protection and attached these also above the nonilluminated treatments for standardization (Fig. S4). The photosynthetically active radiation (PAR) was measured once in all mesocosms at $35 \mathrm{~cm}$ above the soil with a PAR Quantum sensor SKP 215 (Skye Instruments Ltd, Llandrindod Wells, UK) on one day in each region in July 2019 during midday conditions (12:00 h-14:00 h). This measurement was only a snapshot of light availability which changes strongly during daily and seasonal cycles. Furthermore, we measured PAR in the mesocosms between the studied understorey plants, which shaded the sensor when higher than $35 \mathrm{~cm}$. Values can be interpreted as minimum values (also given the summer measurement during full canopy closure) that give a rough estimation of light around mid-day during summer. We used a linear mixed-effect model (LMM) to assess the increase in PAR by the light treatment. The forest structure, edge vs interior position and presence of lamps and infrared heaters were used as fixed effects. Region was added as a random intercept to control for different measurement days and differences in background light availability. Model fit was assessed through marginal and conditional $R^{2}$ values (see the Statistical analyses section). Light addition resulted in a significant increase in PAR of $5.59 \mu \mathrm{mol} \mathrm{m}{ }^{-2} \mathrm{~s}^{-1}$ (95\% confidence interval (CI) (2.83-8.32), $n=380, R_{\mathrm{m}}^{2}=0.24, R_{\mathrm{c}}^{2}=0.31$ ), with average light levels of 20.3 and $26.3 \mu \mathrm{mol} \mathrm{m}^{-2} \mathrm{~s}^{-1}$ for the nonilluminated and illuminated treatments respectively (Fig. S5). The difference in light availability caused by forest structure complexity was larger: locations with a simple forest structure received $15.11 \mu \mathrm{mol} \mathrm{m}{ }^{-2} \mathrm{~s}^{-1}$ (95\% CI (12.30-17.93)) more PAR than structurally complex locations, with average light levels of 14.5 and $27.6 \mu \mathrm{mol} \mathrm{m} \mathrm{m}^{-2} \mathrm{~s}^{-1}$ in control plots of complex vs simple structure stands, respectively (Fig. S6). As such we aimed to create a light gradient with the lowest and second lowest level in control and light treatments respectively in dense stands (+38.6\% relative to dense, control), and brighter $(+90.3 \%)$ and brightest $(+128.9 \%)$ in the simply structured forest under control and light treatments respectively. These are moderate increases in light levels as found in relatively small canopy gaps, as disturbances in beech forests have been shown to cause light increases of $+227 \%$ and $+387 \%$ in distributed and aggregated disturbances, respectively (Thom et al., 2020).

The warming treatment was administered during day and night by two infrared heater arrays of $100 \mathrm{~W}$ (Elstein - Werk M Steinmetz GmbH \& Co. KG, Northeim, Germany). Globally, we have already exceeded $1{ }^{\circ} \mathrm{C}$ climate warming compared to 1850-1900 baseline temperatures (IPCC, 2018). For Europe, projections estimate a further increase of $1.5^{\circ} \mathrm{C}$ by $2081-2100$ in the RCP2.6 scenario and by 2041-2060 potentially in RCP4.5 but definitely in RCP8.5 (compared to 1995-2014) (CORDEX Europe, (Gutiérrez et al., 2021)). Temperatures and soil moisture were measured every $15 \mathrm{~min}$ from 17 May to 30 September in 2019 in the soil $(8 \mathrm{~cm}$ depth $)$, at the surface $(0 \mathrm{~cm}$ height $)$ and in the air $(15 \mathrm{~cm}$ height $)$ in the central mesocosm of control and warming treatments (thus not in light and light + warming treatments) with TMS-4 loggers (TOMST, Prague, Czech Republic) (Wild et al., 2019; Maclean et al., 2021). Both the surface and air temperature sensor were protected from direct sunlight with radiation shields. We used LMMs to assess the change in daily mean temperatures and soil moisture caused by the infrared heaters and the experimental design (Fig. 1). Region, forest structure, edge vs interior position and presence of the heaters were used as fixed effects. Sensor identifier (ID) and day of the measurement were added as random intercepts to control for sensor-specific deviations and seasonal temperature changes respectively. Across all forests and sites, the models showed a significant increase of soil, surface and air daily temperatures under the warming treatment of respectively $1.29^{\circ} \mathrm{C}$ $\left(95 \%\right.$ CI $\left.(0.85-1.73), n=3288, R_{\mathrm{m}}^{2}=0.53, R_{\mathrm{c}}^{2}=0.88\right)$, $1.63^{\circ} \mathrm{C}\left((1.13-2.15), n=3288, R_{\mathrm{m}}^{2}=0.46, R_{\mathrm{c}}^{2}=0.82\right)$ and $1.54^{\circ} \mathrm{C}\left((1.05-2.02), n=3288, R_{\mathrm{m}}^{2}=0.44, R_{\mathrm{c}}^{\mathrm{c}^{\mathrm{c}}}=0.81\right)$ (Fig. S7). In the simpler forest structure both daily surface and air temperatures significantly increased with $0.52^{\circ} \mathrm{C}((0.02-1.02))$ and $0.62^{\circ} \mathrm{C}((0.15-1.10))$ (Fig. S7). We found that the warming treatment significantly reduced the volumetric soil moisture percentage by $7 \%\left((-0.12\right.$ to -0.02$), n=3288, R_{\mathrm{m}}^{2}=0.41$, $R_{\mathrm{c}}^{2}=0.65$ ) (Figs S7, S8). Furthermore, also at the forest edge the soil water content was lower compared to the forest interior by $8 \%((-0.12$ to -0.03$))$ (Fig. S7) and in Sweden the soil moisture was significantly higher than in Belgium by $7 \%$ $((0.01-0.12))$ (Fig. S7). Fluorescent tubes did not measurably affect soil temperatures, as quantified with Lascar EL-USB-1 loggers (Lascar Electronics, Whiteparish, UK) (Figs S9, S10).

Each treatment was applied to nine mesocosm plant communities. In total, the experiment encompassed 432 mesocosms (three regions $\times$ four experimental locations per region $\times$ four treatments per location $\times$ nine mesocosms per treatment). We used plastic trays with 21.51 volume as mesocosms and filled these with potting soil consisting of $85 \%$ peat and $15 \%$ coconut fibre and a $\mathrm{pH}-\mathrm{KCl}$ of 5 to 6.5 . A slow-release $15: 8: 11: 2$ nitrogen : phosphorus : potassium : magnesium fertilizer containing trace elements (Osmocote Exact Low Start 16-18 M, ICL Specialty Fertilizers, Geldermalsen, The Netherlands) was added at an application rate of $4 \mathrm{~g}$ fertilizer per litre potting soil at the beginning of the experiment. By using this potting soil and slowrelease fertilizer, we aimed to keep among-site variability regarding soil characteristics to a minimum. The trays had drainage holes, the mesocosm communities were only watered directly after planting the individuals. Due to the constant radiation energy applied without watering, the warming treatment was associated with lower soil moisture (Figs S7, S8). The effect on 
leaf temperature probably changed through time due to evapotranspiration feedbacks depending on soil moisture (De Boeck et al., 2017), which also happens in natural conditions (De Boeck et al., 2015).

\section{Study species and transplantation into mesocosms}

We created four ecological groups of three species (Table 1). To characterize the species' light preference, we looked at their occurrence in closed forest (forest specialists) or in both forest and open vegetation (generalists), following the EuForPlant database (Heinken et al., 2019). These groups coincided with a gradient in CCI, based on the association with recent forests $(-100)$ compared to ancient forests $(+100)$ (Verheyen et al., 2003; De Frenne et al., 2011) (Table 1). To infer the species' temperature preference, we used thermal niche optima based on the mean annual temperature within the species' distribution range (ClimPlant database; Vangansbeke et al., 2021) (Table 1, see Fig. S1 for distribution maps). All species were sourced from Belgian or German provenances from climatically similar source locations to minimize differences in species responses to the warming treatment caused by local adaptation. They were sourced as seedlings, grown to seedlings from seeds or collected from local source populations in Gontrode (Belgium) (Table 1).

Mesocosm communities consisted of four individuals of four plant species, one from each ecological group. These species were randomly drawn from the groups, but in a stratified design assuring that each species occurred in three out of nine mesocosms of each treatment unit (three replicates per combination of treatment and species). As a consequence, mesocosm communities contain a random combination of one species of each group, while all species occur in equal numbers in each treatment. In total, the experiment encompassed 6912 individual plants (432 mesocosms $\times 16$ individuals per mesocosm) and 576 individuals per species.

\section{Functional trait and cover measurements}

We focused on two key functional traits, plant height and SLA because these are expected to respond to changing environmental conditions such as light and temperature (Poorter et al., 2009; Tinya et al., 2019; Blondeel et al., 2020a), but they also reflect each plants' growth, performance and function. Plant height is clearly linked to the competitive ability of the species, whereas SLA gives more insight in the plant's resource acquisition strategy (Westoby, 1998; Westoby \& Wright, 2006; Diaz et al., 2016). Additionally, we visually estimated the cover of each species in the mesocosm (four individuals together, with a maximum of $100 \%)$ to estimate their overall growth and performance. Overlap between the four species in the mesocosm was allowed (the sum of estimated covers of four species was allowed to surpass 100\%). The experiment started in spring 2019 and the first measurements were done in summer, therefore Anemone nemorosa (a vernal geophyte) was not measured in 2019. In 2020, measurements were performed in spring for Anemone nemorosa, Oxalis acetosella and Allium ursinum and in summer for all other species (Fig. S11).
We measured the natural plant height (without stretching the plant) for all surviving individuals (Tables 1 and S2 for survival per region) (Pérez-Harguindeguy et al., 2016). We took one leaf of one individual per species per mesocosm to measure SLA. Leaves were not collected when no healthy leaves (i.e. without obvious symptoms of pathogen or herbivore attack) were available or when the individuals only had one leaf (Table 1). Since SLA is strongly affected by light intensity, we sampled outer canopy leaves (Pérez-Harguindeguy et al., 2016). The leaves were dried in a drying oven at $40^{\circ} \mathrm{C}$ for $48 \mathrm{~h}$. Subsequently, leaves (without petiole) were scanned to measure its one-sided area with a LI-3000C Portable Area Meter in combination with a LI3050C Transparent Belt Conveyer Accessory (Li-Cor Environmental, Lincoln, NE, USA) and weighed (to $0.1 \mathrm{mg}$ ). SLA was calculated by dividing the leaf area by the oven dried leaf mass (in $\left.\mathrm{mm}^{2} \mathrm{mg}^{-1}\right)$.

\section{Statistical analyses}

All analyses were performed in R v.4.0.3 (R Development Core Team, 2020).

Modelling total plant cover and community weighted mean specific leaf area and plant height Community weighted means (CWM) of plant height and SLA were calculated weighted by the cover of each species in the mesocosm. The total percentage ground cover in each mesocosm was calculated by summing the cover of all species per mesocosm. Then, we used LMMs to infer responses of CWM functional traits and total plant cover (i.e. the set of response variables) to a set of explanatory variables (i.e. the fixed effect variables): light and warming treatments; forest structure (complex vs simple); plot position (edge vs interior); and region (Italy vs Belgium vs Sweden). The CWM for plant height was log-transformed before modelling to increase normality and model fit. All fixed effect variables were coded categorically and all two-way interactions were included (three-way interactions excluded). Year was used as a covariate to account for differences between 2019 and 2020. To account for repeated measurements, mesocosm ID (432 levels corresponding to 432 mesocosms) was used as random intercept (Eqn 1). A post hoc test (Tukey multiple comparison) was performed with the function emmeans (package emmeans) (Lenth, 2021) to assess significant interactions (Fig. 3; see later).

$$
\begin{array}{r}
\text { Response } \sim(\text { light }+ \text { warming }+ \text { forest structure }+ \text { interior } \\
- \text { edge }+ \text { region })^{2}+\text { year }+(1 \mid \text { mesocosm ID }) \\
\text { Eqn } 1
\end{array}
$$

Note that the superscript 2 indicates that all two-way interactions between the variables between brackets are included.

Relating species responses to species characteristics To infer species responses to the treatments, we applied the same model structure to species data of plant height, SLA and cover (Eqn 1). Plant height and SLA were scaled (mean $=0, S D=1)$ per 


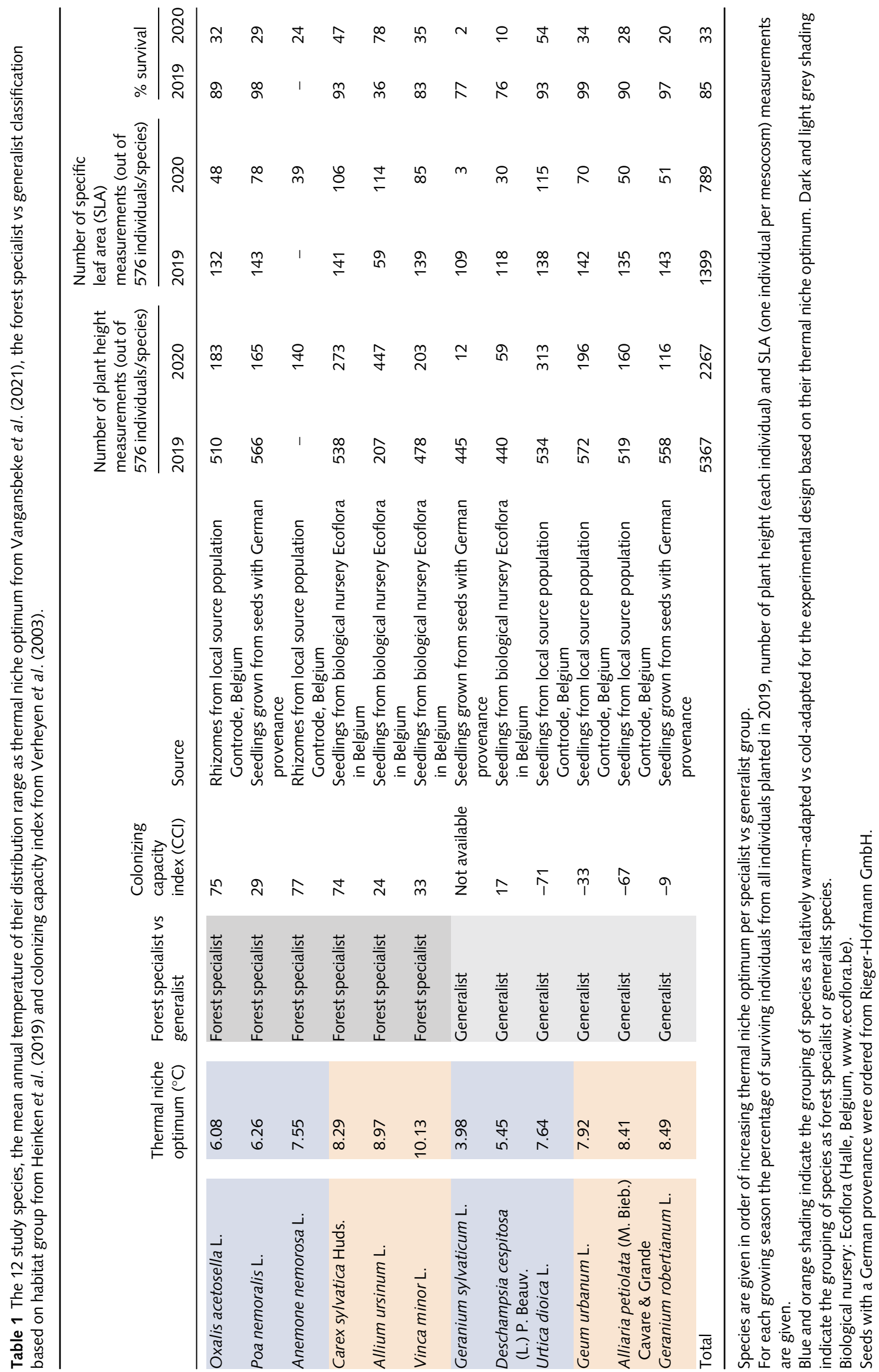


species to ensure comparability. We added the individual plant ID as random intercept as functional trait measurements were repeated on the individual level. For SLA, there was only one measurement per species per mesocosm, therefore the random effect 'mesocosm ID' was removed. We had too few SLA measurements of Anemone nemorosa, to run the model $(n=39)$. The cover data was bound between zero and one and had a high proportion of zero values, therefore we used generalized linear mixed-effects models (GLMMs) instead of LMMs with a zero-inflated beta-distribution (Damgaard \& Irvine, 2019). Such models estimate the probability of absence first (zeroinflated part; ZI part) and then the cover, conditional on the presence of the species, with a beta-distribution (beta-part) (Damgaard \& Irvine, 2019). For both the zero-inflated part and the beta part a 'logit' link function was used and for the additional precision parameter of the beta-distribution (phi) a 'log' link function was used. For Geum urbanum, the zero-inflated distribution did not produce a good model fit, and for Geranium robertianum, the model did not converge. For these two species regular beta distributions were used without zeroinflation. For Geranium sylvaticum, covers and presence were too low to fit a converging model.

To analyse relationships between species characteristics and treatment responses, we used linear models (LMs) with the species coefficient estimates for the light and warming treatment as response variables and species characteristics as predictor variables (CCI and thermal niche optimum). The standard errors on the model estimates were taken into account by the model, which is specified in the brms package as an addition to the response term ('Ise (standard error response)') (Eqn 2). For Geranium sylvaticum there was no CCI available, therefore sample sizes for the LMs with CCI were $n=11 \quad(n=10$ for SLA due to missing estimate for Anemone nemorosa) and $n=12$ for LMs with thermal niche optima ( $n=11$ for SLA). The model estimates used for the regressions represent the situation with all other predictors at reference level (no light, no warming, complex structure, interior, Belgium). When more than one species showed a significant interaction between the treatment and another predictor variable, we changed the reference category of this predictor and re-assessed the LMs (Figs 5, see later, S12-S14).

Estimate|se(standard error of estimate $) \sim 1+$ species characteristic

Eqn 2

All our models (LMMs, GLMMs and LMs) were fitted with the BRMS package, which uses the probabilistic programming language Stan (Bürkner, 2017, 2018). We used four chains, consisting of 2000 iterations after a warm-up of 2000 iterations and used default priors. Convergence and mixing of chains were visually inspected. Using the r2_bayes function, we calculated Bayesian $R^{2}$ values for all models: a marginal $R^{2}$ for the variance explained by fixed effects and a conditional $R^{2}$ for the variance explained by fixed and random effects (Lüdecke et al., 2020). Model parameters are reported as posterior means with 95\% credible intervals, the interval in which the parameter would lie with a $95 \%$ probability, given the evidence of the observed data (Hespanhol et al., 2019).

\section{Results}

\section{Community responses to the warming and light treatments (Hypotheses 1 and 2)}

We found no significant community responses to the warming treatment, nor any interactions with the light treatment, forest structure, edge vs core position or macroclimate conditions. However, we found the understorey strongly responding to the light treatment in interaction with the forest structure and edge vs interior gradients regarding plant height and cover (Fig. 2). The understorey communities increased their plant height and cover in response to light, but only (plant height) or mostly (cover) in plots with a complex forest structure and, for cover, also in the forest interior (Fig. 3). Additionally, the forest structure had a strong impact on the three traits: the communities in plots with a simpler forest structure generally had a lower CWM SLA and higher cover and, in Belgium, also a higher CWM plant height. The regional interactions indicate that forest structure effects were strongest in Belgium (Fig. S15), which was expected as the structural difference between the 'complex' and 'simple' forest structure plots was largest in this region (Table S1). Interestingly, for the total plant cover, we noted an opposite pattern in Italy, where the cover was lower in the stands with a simple forest structure (Fig. S15). Moreover, the CWM SLA was lower at the forest edge compared to the interior in Belgium, whereas this decrease was smaller in Sweden and we even noted an increase in Italy (Fig. S16). The cover of the communities was higher in the forest interior compared to the edge in Belgium, whereas there was no clear difference in Italy, and in Sweden the cover was higher in the forest edge (Fig. S16). Finally, the traits changed significantly over time. We found a decrease in CWM SLA, an increase in CWM plant height and species' plant height in 2020 compared to 2019 (Figs 2, S17-S20). Additionally, the total cover in the mesocosms in 2020 was lower than in 2019 and survival rates were lower for all species except the spring geophyte Allium ursinum (Fig. 2; Table 1). When assessing the relation between the functional traits, we found that the CWM plant height and total cover of communities were positively correlated (Pearson correlation of 0.52 ), whereas there was no relation between the CWM SLA and plant height (Pearson correlation of 0.02), or total cover (Pearson correlation of 0.17) (Fig. S21).

\section{Species responses related to species' characteristics (Hypothesis 3)}

In general, responses differed strongly among species (Figs S17S20). We observed several significant correlations between the response to the light treatment and the species' CCI (Fig. 4). The generalists (with a lower CCI) tended to decrease their SLA and increase their cover more than forest specialists under the light treatment (Fig. 4). We also found that species with a colder thermal niche optimum did not decrease their SLA as much as 


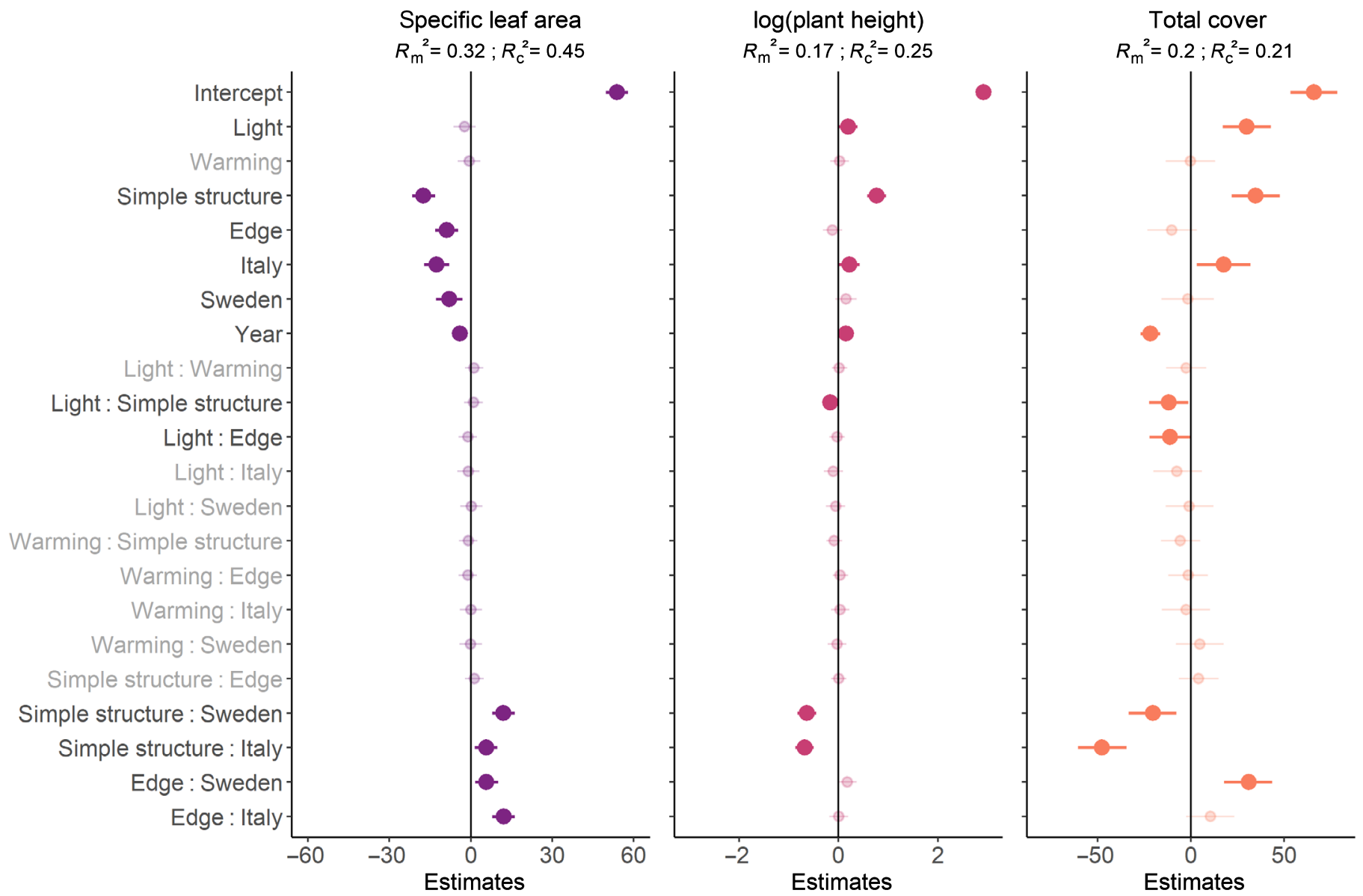

Fig. 2 Estimates and 95\% credible intervals for the explanatory variables in the linear mixed-effect models we ran for the community weighted mean specific leaf area, plant height and total cover. Nonsignificant variables (credible interval overlapping zero) are made transparent. The marginal and conditional $R^{2}$ of the three models are given below the titles. The intercept term is set to 'no light/no warming/complex structure/core position/Belgium' with its estimate significantly deviating (or not) from the zero value while all other estimates are showing significant deviation (or not) from the intercept term.

species with a warmer thermal niche optimum in response to light (Fig. 4). Furthermore, we found significant interactions between the plant height response to light and the forest structure for several species (Figs S17-S20). However, there were no significant regressions of plant height response to light with species' CCI or thermal niche optimum irrespective of forest structure (Fig. S12). Nevertheless, the response to light also changed for some species depending on the region (Figs S17-S20) and reassessing the regression with Italy or Sweden as reference value for estimates showed that in Sweden and Italy, the cold-adapted species increased their plant height more in response to light than the warm-adapted species (Fig. S13).

Species responses to the warming treatment were generally not significant. We did not find strong general correlations with the species' CCI, nor thermal niche optima (Figs 5, S22). However, we did find significant interactions with the region and edge vs interior position for several species (Figs S17-S20). Interestingly, cold-adapted species grew less tall in the warming treatment, but only in Italy (Fig. S14). Furthermore, we noticed a trend of specialists and cold-adapted species to decrease their cover when the warming treatment was applied at the forest edge, but not in the forest interior (nonsignificant slope, but high $R^{2}$ values) (Fig. 5).

\section{Discussion}

\section{Forest structure determines the effect of light addition}

Our findings strongly support the decisive role of forest structure for understorey communities' responses to light (Tinya \& Odor, 2016; Tsai et al., 2018; Lelli et al., 2019; Govaert et al., 2020). In structurally simpler forests, the understorey receives more light and warmth, stimulating growth and resulting in a denser cover (Tinya \& Odor, 2016; Tinya et al., 2019) and taller communities due to higher competition (Tinya et al., 2019; Blondeel et al., 2020b). Recently Gilliam (2019a,b) found that canopy openings only have a positive effect on herbaceous vegetation cover in cases of nitrogen excess. As we used potting soil at all sites, our study was not designed to differentiate responses based on soil characteristics. Nevertheless, soil properties might impact responses to light in natural conditions. The CWM plant height also significantly increased from 2019 to 2020, probably due to 

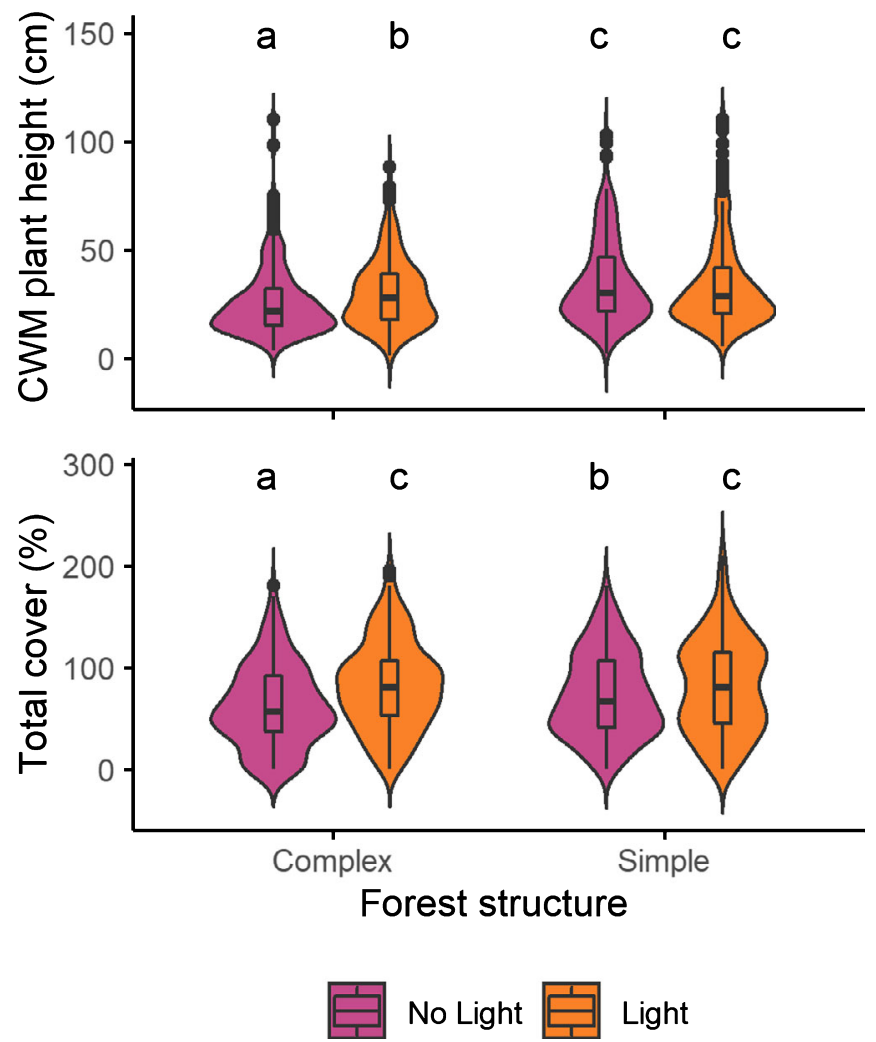

Fig. 3 Violin plots of the community weighted mean data for plant height and of the total plant cover grouped by forest structure and presence or absence of light treatment. This figure illustrates the significant negative interaction between the light treatment and forest structure on the plant height and total cover of the plant communities. A post hoc test (Tukey multiple comparison) was performed to assess significant differences between groups given by letters above the violin plots.

the higher survival of taller species and a lower investment in belowground biomass in 2020 . The total cover in the mesocosms, however, decreased, as mortality increased, possibly due to increased competition for belowground space in the mesocosms.

Regarding SLA, plants have smaller, thicker leaves in structurally simpler forests because an increase in photosynthetic surface area does not outweigh the advantage of a larger mass investment per leaf increasing the number of chloroplasts and photosynthetic capacity per unit leaf surface (Evans \& Poorter, 2001; Burton et al., 2017; Chelli et al., 2019; Blondeel et al., 2020b). We report similar responses of the community to the light treatment (see Fig. 2), corroborating light availability as driver of understorey responses to forest structure. CWM SLA decreased when the forest structure was simpler (compared to complex), but the response to light addition was not so strong, nor significant (Fig. 2). This could be explained by the larger contrast in light availability caused by different forest structural types than by the light treatment itself (15.11 vs $5.59 \mu \mathrm{mol} \mathrm{m}{ }^{-2} \mathrm{~s}^{-1}$ PAR).

The composition and cover of tree and shrub layer differed by region, which is reflected in the regional dependence of understorey responses to forest structure (Figs 2, S15). Furthermore, macroclimatic differences by region interacted with microclimatic differences due to forest complexity. For example, total plant cover of the communities was higher in the plots with a simple forest structure, but not in the warmest region (Italy) (Fig. S15). Probably, the less buffered microclimate (Fig. S7) amplified drought effects and temperature extremes in this region. Additionally, forest structure determined the strength of the cover and plant height responses to the light treatment. The light availability is generally higher at the forest edge, in a stand with a simpler structure, or in early- to mid-successional forests (Matlack, 1993; Neufeld \& Young, 2014; Tsai et al., 2018). Therefore, an addition of light by a tree fall or forest management will not be of such high significance, relatively speaking, for the understorey as it is in dense, shady forests (Valladares et al., 2016). Hence baseline conditions regarding light matter for a similar increase in light availability.

\section{Warming did not affect the understorey community}

We expected increases in plant height and cover and a decrease in SLA under the warming treatment as reported in experimental (Blondeel et al., 2020a,b) and observational studies (Moles et al., 2014; Chelli et al., 2019; Maes et al., 2020). However, the warming treatment did not cause such response, even though the plants experienced an increase of $\pm 1.5^{\circ} \mathrm{C}$ for two growing seasons, an increase which can be expected to occur in Europe within this century (Gutiérrez et al., 2021). Some experimental studies reported a stronger response of understorey communities to light addition than to short-term experimental warming ( $\mathrm{Ma} e t$ al., 2018; Blondeel et al., 2020b; Kennard et al., 2020). Another study, including woody species, noted that light addition amplified the response to warming (De Frenne et al., 2015; Govaert et al., 2021). Even when light was added to the warming treatment, we recorded no response in community traits or cover. This result suggests a stronger impact of a relatively small addition of light (compared to the light increase after large-scale canopy disturbances) for the herbaceous understorey than a rise in sub-canopy temperature of $1.5^{\circ} \mathrm{C}$, predicted for Europe in this century (Gutiérrez et al., 2021). Furthermore, plant height and cover are related to species' growth, and photosynthesis is directly dependent on light availability, especially in the shady understorey, photosynthetic rates would increase strongly for each increase in PAR (Smith \& Smith, 2012). Temperature acts more as a regulator of the process, affecting the rate of photosynthesis for a given amount of PAR (Lewis et al., 1999; Smith \& Smith, 2012). The relationship between photosynthesis (and growth-related measures) and temperature might thus not be as straightforward and plants might respond to warming through other characteristics, such as phenology or reproductive output (Jacques et al., 2015; Willems et al., 2021).

Nevertheless, climate change happens at a slower and more continuous pace than our experimental treatment and several studies already showed that long-term global warming changed understories over the last decade(s) (Becker-Scarpitta et al., 2019; Zellweger et al., 2020; Govaert et al., 2021; Richard et al., 2021) but see Becker-Scarpitta et al. (2017). Our results show that understorey communities might not respond to warming, or at 

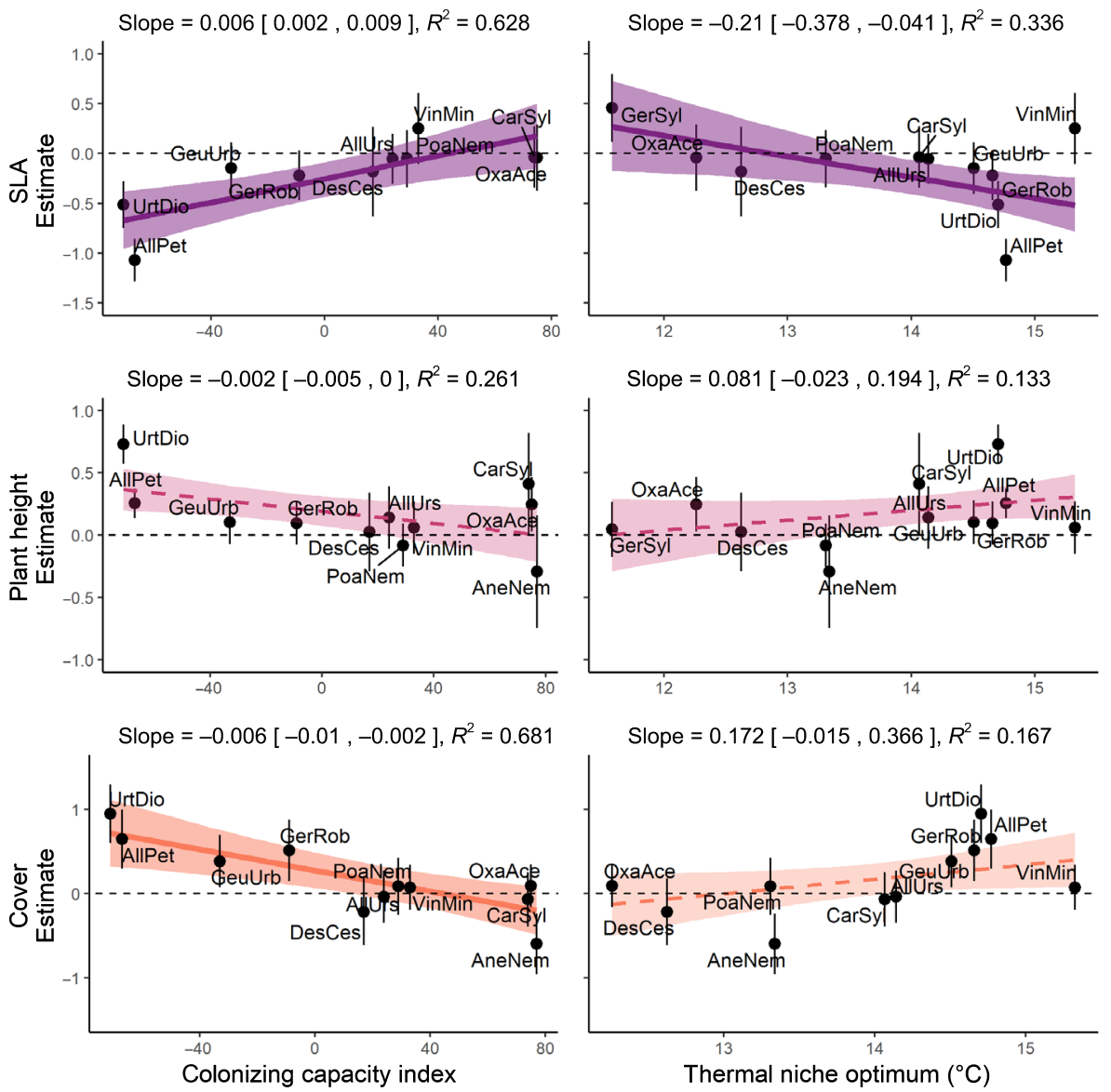

Generalist

$\leftrightarrow$

Forest specialist

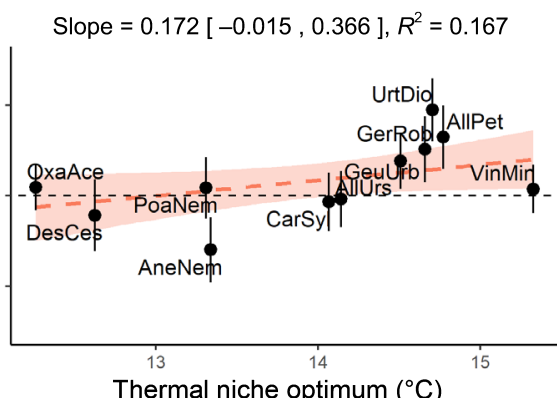

Cold-adapted $\leftrightarrow \quad$ Warm-adapted
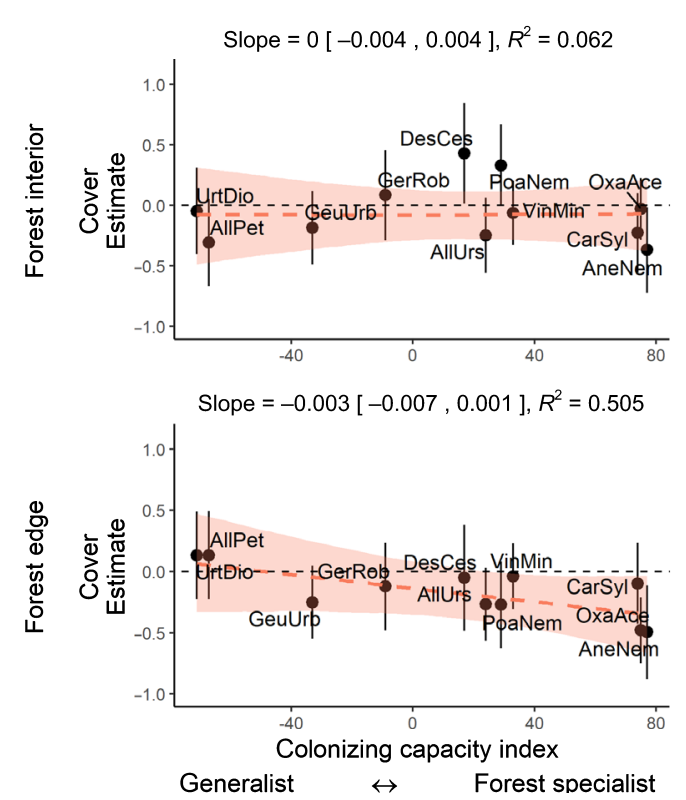

Slope $=-0.067[-0.271,0.132], R^{2}=0.096$

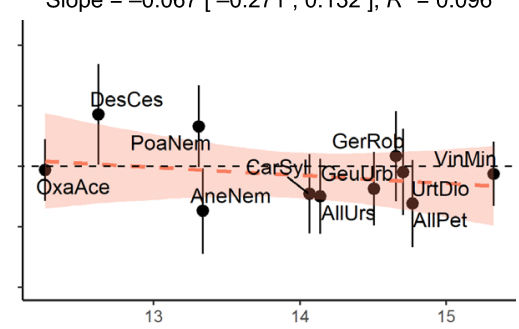

Slope $=0.143[-0.057,0.335], R^{2}=0.409$
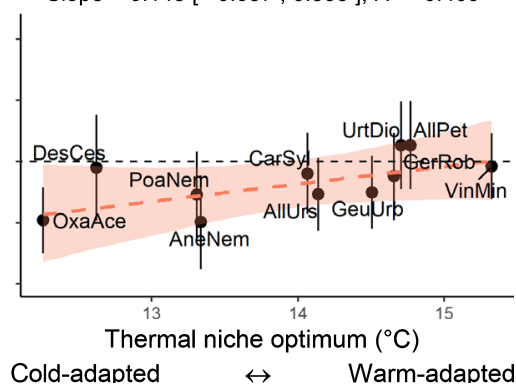

$\leftrightarrow \quad$ Warm-adapted
Fig. 4 Linear regressions of the species responses to the light treatment with the species' colonizing capacity index and thermal niche optimum. Positive (respectively negative) parameter estimates reflect that plant traits and cover (beta-part expressing a change in cover given the presence of the species) responded positively (negatively) to the enhanced illumination. Black points and lines give the model estimates and standard errors for the light treatment for each species (G)LMMs, with all other factors at reference level (no warming, forest interior, complex forest structure and Belgian region). Full and dashed regression lines represent significant (credible interval not overlapping zero) and nonsignificant slopes respectively. Shading corresponds to $95 \%$ credible intervals.
Fig. 5 Linear regressions of the species' cover response to the warming treatment for forest interior and forest edge with the species' colonizing capacity index and thermal niche optimum. These are estimates of the beta-part expressing a change in cover given the presence of the species. Black points and lines give the model estimates and standard errors for the warming treatment for each species (G)LMMs. Model estimates are given for the forest edge and forest interior positions, with all other factors at reference level (no additional light, complex forest structure and Belgian region). Dashed regression lines represent nonsignificant slopes. Shading corresponds to $95 \%$ credible intervals. least not respond immediately regarding cover or functional traits. A time-lag in response to warming, also called 'climatic debt' (Bertrand et al., 2011; Richard et al., 2021) is possible and could cause a discrepancy between short-term experimental warming results, long-term observational or environmental gradient studies and climate change. Such differences are not uncommon. Wolkovich et al. (2012), for example, found globally much smaller phenological responses to short-term experimental than 
to long-term observed climate warming (and see Elmendorf et al. (2015)). However, experiments would need to span longer to assess the duration of a time-lag or the continued resistance of understorey communities (Cusser et al., 2021). Furthermore, we only measured adult individuals, whereas warming could impact other life stages (e.g. germination, establishment) significantly and influence long-term community composition. Additionally, the total cover in the mesocosms decreased from 2019 to 2020, and for all species (except Allium ursinum) survival rates dropped. As a consequence, our sample size decreased, lowering our statistical power to detect subtle responses.

Moreover, in our study, the warming treatment was only applied during the growing season and some plants might respond to growing season length or warming outside the growing season for dormancy breaking or seed germination (Walck et al., 2011; Orru et al., 2012; Flanigan et al., 2020; Newton et al., 2020), affecting species' reproduction and the community composition over a longer time period. Additionally, experimental warming inherently reduces soil moisture (Ettinger et al., 2019), as in our experiment (Fig. S7), whereas natural precipitation patterns are variably affected by climate change (Dore, 2005; Dagan et al., 2019). But perhaps most importantly, climate change does not affect plant communities in isolation. In reality, indirect effects are simultaneously acting with warming. The latter can affect herbivores, pathogens, mycorrhiza and pollinators as well as soil processes, all of which impact understorey plants and could influence responses to climate change (Kudo \& Ida, 2013; Gaudio et al., 2015; Velásquez et al., 2018; Bennett \& Classen, 2020; Hamann et al., 2021). Also, in our experiment we found a high variation in mortality among species, sites and years which we could not attribute to the studied traits or treatments (Tables 1, S2). Therefore, it is necessary to acknowledge the artificiality when interpreting findings of experiments. Even though they are highly useful to study the single effect of warming, complementation with long-term observational and environmental gradient studies is necessary (De Frenne et al., 2013a).

\section{Life history syndrome dictates species responses to light}

The community response to light is driven mainly by generalists, such as Urtica dioica and Alliaria petiolata, which increased in cover and decreased their SLA. The generalists are fast colonizers, typically among the first to colonize early-successional forests, they are stronger competitors and adapted to a wider range of light conditions, as they occur in both forests and more open habitats (Verheyen et al., 2003; Heinken et al., 2019). Having a lower SLA, they tend to allocate more resources to rapid growth in height while sustaining sufficient leaf area for photosynthesis in an illuminated environment. This provided a competitive advantage over forest specialists, such as Vinca minor or Oxalis acetosella, which tend to have a more stresstolerant strategy (Hermy et al., 1999) and did not show signifcantly lower SLA or increased cover as response to the light treatment. Contrarily, Chelli et al. (2021) found that forest specialists showed greater intraspecific variation in SLA. Also phenology and leaf physiology could be important here. Three out of six forest specialists in this experiment are spring ephemerals, growing before tree canopy flush (shade avoiders). Possibly, the light treatment did not add an ecologically significant amount of light for these species during spring. Shadetolerant species, contrarily, have generally lower light saturation and compensation points, enabling them to sustain photosynthesis in the darker understorey, but resulting in lower photosynthesis rates in bright conditions (Taylor \& Pearcy, 1976). Perhaps, forest specialists have lower light saturation and compensation points compared to generalists. Furthermore, for some shade-tolerant herbs, photosynthetic acclimation to brighter periods (e.g. spring) has been shown (Rothstein \& Zak, 2001). Thus, investigating the potential photosynthetic acclimation of forest specialists and generalists would be highly interesting.

In the future, the habitat and cover of generalists is likely to increase as canopies are expected to open up by storms, disturbances, pest-outbreaks, drought or thinning (Sohn et al., 2016; Jump et al., 2017; Jactel et al., 2019; Senf \& Seidl, 2020). This could lead to biotic homogenization of the forest understorey and potentially cause a decline in biodiversity at the biome-scale (Staude et al., 2020). For spring ephemeral forest specialists, such as Anemone nemorosa, an increase in summer-flowering generalists might not necessarily increase aboveground competition due to different temporal niches (Bratton, 1976; Pigott, 1982). However, generalists might outcompete summer-flowering forest specialists and eventually cause their disappearance from those communities. Therefore, it is important to protect larger forests with forest interior conditions and to preserve dense canopies to complement the expected future increase in forest gap and edge conditions. As such, temperate forests might keep providing a mosaic of light levels and conserve both generalists and specialists in the understorey.

\section{Species responses to warming are small, context- and species-dependent}

Even though there were no significant community-responses to warming, some species did respond to warming, though responses varied with macroclimate or microclimate. In the warmest region (Italy), we found that cold-adapted species, such as Oxalis acetosella and Deschampsia cespitosa, responded more negatively to the experimental microclimate warming compared to warm-adapted species regarding plant height (Fig. S14). For some of the cold-adapted species, Italy is directly at the southern distribution edge (Fig. S1). This finding suggests that southern edge populations of cold-adapted species will first experience negative implications of climate change (Jump et al., 2006; Lesica \& Crone, 2017). However, we used plants of Belgian and German provenances, southern populations might be better adapted to warmer temperatures, cancelling our result. Therefore, including individuals from different climatic provenances and performing a reciprocal transplant experiment is timely to investigate local climate adaptation (Palacio-Lopez et al., 2015). 
Additionally, we noted that in the forest edge both specialists and cold-adapted species tended to decrease in cover with microclimate warming. The regressions were not significant (but had a high $R^{2}$ value, suggesting a potential lack of statistical power given the low sample size: $n=11$ or 12). For Oxalis acetosella and Poa nemoralis, the interaction between warming and distance to the forest edge was significant, it is worrisome that these coldadapted species already showed declines of plant cover at the forest edge after only two years of microclimate warming. Coldadapted forest specialists might respond first, whereas coldadapted generalists might also lose cover with more warming over time. For cold-adapted forest specialists, forest interior conditions with a dense canopy might provide refugia from rising temperatures (Greiser et al., 2020).

\section{Conclusion and outlook}

Our results underpin that light, on the short term, strongly determines understorey plant cover and species' functional traits such as plant height and SLA. Changes in light levels often happen instantaneously and change understorey communities thoroughly and for an extended time period (Tsai et al., 2018). We might expect that, on the short term, indirect impacts, via the effects of climate change on canopy disturbances due to droughts, windstorms or insect attacks (Sohn et al., 2016; Jump et al., 2017; Jactel et al., 2019; Dietz et al., 2020; Senf \& Seidl, 2020) might be as strong or even stronger on understorey vegetation than direct effects of rising temperatures on the understorey plants.

Despite the large number of transplanted individuals, the different microclimate gradients, the full-factorial light and warming treatment and continental scale, our study still has some limitations. To infer more general relationships between climate change sensitivity and species' characteristics, data on a larger number of species is necessary as well as long-term data (de Bello et al., 2020; Govaert et al., 2021). We welcome further multispecies experiments to explore the effect on forest understorey communities of different levels, duration and timing of warming, as well as combinations with precipitation regimes. Furthermore, given the local adaptation of plants and their seeds, it would be highly interesting to explore the effects of warming on plants from sources across the latitudinal gradient. Finally, the longterm impact might differ strongly from short-term responses and could depend on local microclimates, as suggested by Zellweger et al. (2020). To complement long-term observational studies, we advocate long-term warming experiments, such as the international tundra experiment (ITEX) (Henry \& Molau, 1997; Edwards \& Henry, 2016), but stress the need to include differences in forest structure and microclimate. It is striking that there are actually very few forest-floor warming experiments, despite the importance of forest understories for ecosystem functioning and biodiversity (Gilliam, 2007; Landuyt et al., 2019). Additionally, it is crucial to expand the timespan of available microclimate data. The start of global microclimate sensor networks, such as SoilTemp, will provide interesting opportunities to relate longterm understorey responses to measurements of the local microclimate in a very detailed way in the future (Lembrechts et al., 2020, 2021).

\section{Acknowledgements}

The authors thank Luc Willems, Robbe De Beelde, Kris Ceunen for technical support with the experiment. The authors thank Ulf Johanssen, Hans Rudolf Schaffner for their support in Sweden and Italian sites. The authors thank Sarah Vaneenooghe, Jonathan Van Loo, Sam Van Bouchaute, Linnea Glav Lundin and Ove Eriksson for fieldwork help. This work was supported by the Research Foundation Flanders (FWO) (K.D.P. ASP03519, S.G. G0H1517N), the European Research Council (ERC) (ERC Starting Grant FORMICA 757833, 2018, http://www. formica.ugent.be) and the FWO Scientific research network FLEUR (http://www.fleur.ugent.be).

\section{Author contributions}

PDF, KDP, PS, PV and KV conceived the ideas and designed methodology; all authors collected data; KDP analysed the data and led the writing of the manuscript in close collaboration with PDF, LD, PV and KV. All authors (CM, EDL, SG, TV, JB, SAOC, CG, P-OH, GI, JL, JP, FSelvi, FSpicher, JU-D) contributed critically to the drafts and gave final approval for publication.

\section{ORCID}

Jörg Brunet (iD https://orcid.org/0000-0003-2667-4575

Sara A. O. Cousins (iD https://orcid.org/0000-0003-2656-2645

Pieter De Frenne (ID https://orcid.org/0000-0002-8613-0943

Emiel De Lombaerde (D) https://orcid.org/0000-0002-0050-

2735

Karen De Pauw (D) https://orcid.org/0000-0001-8369-2679

Leen Depauw (ID https://orcid.org/0000-0001-5703-6811

Cristina Gasperini (D) https://orcid.org/0000-0002-2713-010X

Sanne Govaert (iD https://orcid.org/0000-0002-8939-1305

Per-Ola Hedwall (D) https://orcid.org/0000-0002-0120-7420

Giovanni Iacopetti (D) https://orcid.org/0000-0002-1472-4435

Jonathan Lenoir (D) https://orcid.org/0000-0003-0638-9582

Camille Meeussen (DD https://orcid.org/0000-0002-5869-4936

Jan Plue (iD https://orcid.org/0000-0002-6999-669X

Pieter Sanczuk (iD https://orcid.org/0000-0003-1107-4905

Federico Selvi (iD https://orcid.org/0000-0002-3820-125X

Fabien Spicher (D) https://orcid.org/0000-0002-9999-955X

Jaime Uria-Diez (D) https://orcid.org/0000-0003-3749-0181

Thomas Vanneste (D) https://orcid.org/0000-0001-5296-917X

Pieter Vangansbeke (iD https://orcid.org/0000-0002-6356-2858

Kris Verheyen (D) https://orcid.org/0000-0002-2067-9108

\section{Data availability}

The raw data is available on Figshare. For plant height and SLA: https://doi.org/10.6084/m9.figshare.14763528.v2

For plant cover: https://doi.org/10.6084/m9.figshare.14763501. v2 


\section{References}

Angelini A, Corona P, Chianucci F, Portoghesi L. 2015. Structural attributes of stand overstory and light under the canopy. Annals of Silvicultural Research 39: 23-31.

Barbati A, Marchetti M, Chirici G, Corona P. 2014. European forest types and forest Europe SFM indicators: tools for monitoring progress on forest biodiversity conservation. Forest Ecology and Management 321: 145-157.

Becker-Scarpitta A, Bardat J, Lalanne A, Vellend M. 2017. Long-term community change: bryophytes are more responsive than vascular plants to nitrogen deposition and warming. Journal of Vegetation Science 28: 12201229.

Becker-Scarpitta A, Vissault S, Vellend M. 2019. Four decades of plant community change along a continental gradient of warming. Global Change Biology 25: 1629-1641.

de Bello F, Valencia E, Ward D, Hallett L. 2020. Why we still need permanent plots for vegetation science. Journal of Vegetation Science 31: 679-685.

Bennett AE, Classen AT. 2020. Climate change influences mycorrhizal fungalplant interactions, but conclusions are limited by geographical study bias. Ecology 101: e02978.

Bertrand R, Lenoir J, Piedallu C, Riofrio-Dillon G, de Ruffray P, Vidal C, Pierrat JC, Gegout JC. 2011. Changes in plant community composition lag behind climate warming in lowland forests. Nature 479: 517-520.

Blondeel H, Perring MP, De Lombaerde E, Depauw L, Landuyt D, Govaert S, Maes SL, Vangansbeke P, De Frenne P, Verheyen K. 2020a. Individualistic responses of forest herb traits to environmental change. Plant Biology 22: 601614.

Blondeel H, Perring MP, Depauw L, De Lombaerde E, Landuyt D, De Frenne P, Verheyen K. 2020b. Light and warming drive forest understorey community development in different environments. Global Change Biology 26: 1681-1696.

Blondeel H, Remy E, Perring MP, Landuyt D, Bodé S, De Frenne P, Boeckx P, Verheyen K. 2019. Larger direct than indirect effects of multiple environmental changes on leaf nitrogen of forest herbs. Plant and Soil 445: 199-216.

Bramer I, Anderson BJ, Bennie J, Bladon AJ, De Frenne P, Hemming D, Hill RA, Kearney MR, Korner C, Korstjens AH et al. 2018. Advances in monitoring and modelling climate at ecologically relevant scales. In: Bohan DA, Dumbrell AJ, Woodward G, Jackson M, eds. Next generation biomonitoring, Pt 1. San Diego, CA, USA: Elsevier Academic Press, 101-161.

Bratton SP. 1976. Resource division in an understory herb community: responses to temporal and microtopographic gradients. American Naturalist 110: 679693.

Brodribb TJ, Powers J, Cochard H, Choat B. 2020. Hanging by a thread? Forests and drought. Science 368: 261-266.

Bürkner P-C. 2017. BRMS: an R package for Bayesian multilevel models using stan. Journal of Statistical Software 80: 1-28.

Bürkner P. 2018. Advanced Bayesian multilevel modeling with the R package BRMS. The R Journal 10: 395.

Burton JI, Perakis SS, McKenzie SC, Lawrence CE, Puettmann KJ. 2017. Intraspecific variability and reaction norms of forest understorey plant species traits. Functional Ecology 31: 1881-1893.

Chelli S, Ottaviani G, Simonetti E, Campetella G, Wellstein C, Bartha S, Cervellini M, Canullo R. 2021. Intraspecific variability of specific leaf area fosters the persistence of understorey specialists across a light availability gradient. Plant Biology 23: 212-216.

Chelli S, Simonetti E, Wellstein C, Campetella G, Carnicelli S, Andreetta A, Giorgini D, Puletti N, Bartha S, Canullo R. 2019. Effects of climate, soil, forest structure and land use on the functional composition of the understorey in Italian forests. Journal of Vegetation Science 30: 1110-1121.

Chen JQ, Saunders SC, Crow TR, Naiman RJ, Brosofske KD, Mroz GD, Brookshire BL, Franklin JF. 1999. Microclimate in forest ecosystem and landscape ecology - variations in local climate can be used to monitor and compare the effects of different management regimes. BioScience 49: 288-297.

Cusser S, Helms J IV, Bahlai CA, Haddad NM. 2021. How long do population level field experiments need to be? Utilising data from the 40-year-old LTER network. Ecology Letters 24: 1103-1111.
Dagan G, Stier P, Watson-Parris D. 2019. Analysis of the atmospheric water budget for elucidating the spatial scale of precipitation changes under climate change. Geophysical Research Letters 46: 10504-10511.

Damgaard CF, Irvine KM. 2019. Using the beta distribution to analyse plant cover data. Journal of Ecology 107: 2747-2759.

Davies Colley R, Payne G, Elswijk MV. 2000. Microclimate gradients across a forest edge. New Zealand Journal of Ecology 24: 111-121.

Davis KT, Dobrowski SZ, Holden ZA, Higuera PE, Abatzoglou JT. 2019. Microclimatic buffering in forests of the future: the role of local water balance. Ecography 42: 1-11.

De Boeck HJ, Kockelbergh F, Nijs I. 2017. More realistic warming by including plant feedbacks: a new field-tested control method for infrared heating. Agricultural and Forest Meteorology 237: 355-361.

De Boeck HJ, Vicca S, Roy J, Nijs I, Milcu A, Kreyling J, Jentsch A, Chabbi A, Campioli M, Callaghan T et al. 2015. Global change experiments: challenges and opportunities. BioScience 65: 922-931.

De Frenne P, Baeten L, Graae BJ, Brunet J, Wulf M, Orczewska A, Kolb A, Jansen I, Jamoneau A, Jacquemyn $\mathrm{H}$ et al. 2011. Interregional variation in the floristic recovery of post-agricultural forests. Journal of Ecology 99: 600-609.

De Frenne P, Lenoir J, Luoto M, Scheffers BR, Zellweger F, Aalto J, Ashcroft MB, Christiansen DM, Decocq G, De Pauw K et al. 2021. Forest microclimates and climate change: importance, drivers and future research agenda. Global Change Biology 27: 2279-2297.

De Frenne P, Graae BJ, Rodríguez-Sánchez F, Kolb A, Chabrerie O, Decocq G, Kort H, Schrijver AN, Diekmann M, Eriksson O et al. 2013a. Latitudinal gradients as natural laboratories to infer species' responses to temperature. Journal of Ecology 101: 784-795.

De Frenne P, Rodriguez-Sanchez F, Coomes DA, Baeten L, Verstraeten G, Vellend M, Bernhardt-Romermann M, Brown CD, Brunet J, Cornelis J et al. 2013b. Microclimate moderates plant responses to macroclimate warming. Proceedings of the National Academy of Sciences, USA 110: 18561-18565.

De Frenne P, Rodriguez-Sanchez F, De Schrijver A, Coomes DA, Hermy M, Vangansbeke P, Verheyen K. 2015. Light accelerates plant responses to warming. Nature Plants 1: 3.

De Frenne P, Zellweger F, Rodriguez-Sanchez F, Scheffers BR, Hylander K, Luoto M, Vellend M, Verheyen K, Lenoir J. 2019. Global buffering of temperatures under forest canopies. Nature Ecology \& Evolution 3: 744-749.

De Smedt P, Vangansbeke P, Bracke R, Schauwvliege W, Willems L, Mertens J, Verheyen K. 2019. Vertical stratification of moth communities in a deciduous forest in Belgium. Insect Conservation and Diversity 12: 121-130.

Depauw L, Perring MP, Landuyt D, Maes SL, Blondeel H, De Lombaerde E, Brūmelis G, Brunet J, Closset-Kopp D, Czerepko J et al. 2019. Light availability and land-use history drive biodiversity and functional changes in forest herb layer communities. Journal of Ecology 108: 1411-1425.

Díaz S, Kattge J, Cornelissen JHC, Wright IJ, Lavorel S, Dray S, Reu B, Kleyer M, Wirth C, Colin Prentice I et al. 2016. The global spectrum of plant form and function. Nature 529: 167-171.

Dietz L, Collet C, Dupouey J-L, Lacombe E, Laurent L, Gégout J-C. 2020. Windstorm-induced canopy openings accelerate temperate forest adaptation to global warming. Global Ecology and Biogeography 29: 2067-2077.

Dore MHI. 2005. Climate change and changes in global precipitation patterns: what do we know? Environment International 31: 1167-1181.

Eaton E, Caudullo G, Oliveira S, de Rigo D. 2016. Quercus robur and Quercus petraea in Europe: distribution, habitat, usage and threats. In: San-MiguelAyanz J, de Rigo D, Caudullo G, Houston Durrant T, Mauri A, eds. European atlas of forest tree species. Luxembourg: Publication Office of the European Union, 160-163.

Edwards M, Henry GHR. 2016. The effects of long-term experimental warming on the structure of three high arctic plant communities. Journal of Vegetation Science 27: 904-913.

Ehbrecht M, Schall P, Ammer C, Fischer M, Seidel D. 2019. Effects of structural heterogeneity on the diurnal temperature range in temperate forest ecosystems. Forest Ecology and Management 432: 860-867.

Ehbrecht M, Schall P, Ammer C, Seidel D. 2017. Quantifying stand structural complexity and its relationship with forest management, tree species diversity and microclimate. Agricultural and Forest Meteorology 242: 1-9. 
Ellis CJ, Eaton S. 2021. Microclimates hold the key to spatial forest planning under climate change: cyanolichens in temperate rainforest. Global Change Biology 27: 1915-1926.

Elmendorf SC, Henry GHR, Hollister RD, Fosaa AM, Gould WA, Hermanutz L, Hofgaard A, Jónsdóttir IS, Jorgenson JC, Lévesque E et al. 2015. Experiment, monitoring, and gradient methods used to infer climate change effects on plant communities yield consistent patterns. Proceedings of the National Academy of Sciences, USA 112: 448-452.

Estreguil C, Caudullo G, de Rigo D, San MJ. 2012. Forest landscape in Europe: pattern, fragmentation and connectivity EUR 25717. Luxembourg (Luxembourg): Joint Research Centre JRC77295.

Ettinger AK, Chuine I, Cook BI, Dukes JS, Ellison AM, Johnston MR, Panetta AM, Rollinson CR, Vitasse Y, Wolkovich EM. 2019. How do climate change experiments alter plot-scale climate? Ecology Letters 22: 748-763.

Evans JR, Poorter H. 2001. Photosynthetic acclimation of plants to growth irradiance: the relative importance of specific leaf area and nitrogen partitioning in maximizing carbon gain. Plant, Cell \& Environment 24: 755-767.

Farnsworth EJ, Nunez-Farfan J, Careaga SA, Bazzaz FA. 1995. Phenology and growth of three temperate forest life forms in response to artificial soil warming. Journal of Ecology 83: 967-977.

Feeley KJ, Bravo-Avila C, Fadrique B, Perez TM, Zuleta D. 2020. Climatedriven changes in the composition of New World plant communities. Nature Climate Change 10: 965-970.

Fick SE, Hijmans RJ. 2017. WORLDCLIM 2: new 1-km spatial resolution climate surfaces for global land areas. International Journal of Climatology 37: 43024315.

Flanigan NP, Bandara R, Wang F, Jastrzebowski S, Hidayati SN, Walck JL. 2020. Germination responses to winter warm spells and warming vary widely among woody plants in a temperate forest. Plant Biology 22: 1052-1061.

Frey SJK, Hadley AS, Johnson SL, Schulze M, Jones JA, Betts MG. 2016. Spatial models reveal the microclimatic buffering capacity of old-growth forests. Science Advances 2: 9.

Gaudio N, Belyazid S, Gendre X, Mansat A, Nicolas M, Rizzetto S, Sverdrup H, Probst A. 2015. Combined effect of atmospheric nitrogen deposition and climate change on temperate forest soil biogeochemistry: a modeling approach. Ecological Modelling 306: 24-34.

Gehlhausen SM, Schwartz MW, Augspurger CK. 2000. Vegetation and microclimatic edge effects in two mixed-mesophytic forest fragments. Plant Ecology 147: 21-35.

Gilliam FS. 2007. The ecological significance of the herbaceous layer in temperate forest ecosystems. BioScience 57: 845-858.

Gilliam FS. 2019a. Excess nitrogen in temperate forest ecosystems decreases herbaceous layer diversity and shifts control from soil to canopy structure. Forests 10: 13

Gilliam FS. 2019b. Response of herbaceous layer species to canopy and soil variables in a central Appalachian hardwood forest ecosystem. Plant Ecology 220: 1131-1138.

Govaert S, Meeussen C, Vanneste T, Bollmann K, Brunet J, Cousins SAO, Diekmann M, Graae BJ, Hedwall P-O, Heinken T et al. 2020. Edge influence on understorey plant communities depends on forest management. Journal of Vegetation Science 31: 281-292.

Govaert S, Vangansbeke P, Blondeel H, Steppe K, Verheyen K, De Frenne P. 2021. Rapid thermophilization of understorey plant communities in a 9 yearlong temperate forest experiment. Journal of Ecology 109: 2434-2447.

Graae BJ, Sunde PB. 2000. The impact of forest continuity and management on forest floor vegetation evaluated by species traits. Ecography 23: 720-731.

Greiser C, Ehrlén J, Meineri E, Hylander K. 2020. Hiding from the climate: characterizing microrefugia for boreal forest understory species. Global Change Biology 26: 471-483.

Grossiord C, Buckley TN, Cernusak LA, Novick KA, Poulter B, Siegwolf RTW, Sperry JS, McDowell NG. 2020. Plant responses to rising vapor pressure deficit. New Phytologist 226: 1550-1566.

Gutiérrez JM, Jones RG, Narisma GT, Alves LM, Amjad M, Gorodetskaya IV, Grose M, Klutse NAB, Krakovska S, Li J et al. 2021. Atlas. In: MassonDelmotte V, Zhai P, Pirani A, Connors SL, Péan C, Berger S, Caud N, Chen Y, Goldfarb L, Gomis MI, Huang M, Leitzell K, Lonnoy E, Matthews JBR, Maycock TK, Waterfield T, Yelekçi O, Yu R, Zhou B, eds. Climate change
2021: the physical science basis. Contribution of working group I to the sixth assessment report of the intergovernmental panel on climate change. Cambridge, UK: Cambridge University Press.

Hamann E, Blevins C, Franks SJ, Jameel MI, Anderson JT. 2021. Climate change alters plant-herbivore interactions. New Phytologist 229: 1894-1910.

Hedwall P-O, Skoglund J, Linder S. 2015. Interactions with successional stage and nutrient status determines the life-form-specific effects of increased soil temperature on boreal forest floor vegetation. Ecology and Evolution 5: 948960.

Heinken T, Diekmann M, Liira J, Orczewska A, Brunet J, Chytrý M, Chabrerie O, De Frenne P, Decocq G, Dřevojan P et al. 2019. European forest plant species list [accessed 1 September 2020]. doi: 10.6084/m9. figshare.8095217.v1.

Henry GHR, Molau U. 1997. Tundra plants and climate change: the International Tundra Experiment (ITEX). Global Change Biology 3: 1-9.

Hermy M, Honnay O, Firbank L, Grashof-Bokdam C, Lawesson JE. 1999. An ecological comparison between ancient and other forest plant species of Europe, and the implications for forest conservation. Biological Conservation 91: 9-22.

Hespanhol L, Vallio CS, Costa LM, Saragiotto BT. 2019. Understanding and interpreting confidence and credible intervals around effect estimates. Brazilian Journal of Physical Therapy 23: 290-301.

Honnay O, Verheyen K, Hermy M. 2002. Permeability of ancient forest edges for weedy plant species invasion. Forest Ecology and Management 161: $109-122$.

IPCC. 2018. Global warming of $1.5^{\circ} \mathrm{C}$. An IPCC special report on the impacts of global warming of $1.5^{\circ} \mathrm{C}$ above pre-industrial levels and related global greenhouse gas emission pathways, in the context of strengthening the global response to the threat of climate change, sustainable development, and efforts to eradicate poverty. Geneva, Switzerland: World Meteorological Organization.

Jacques M-H, Lapointe L, Rice K, Montgomery R, Stefanski A, Reich P. 2015. Responses of two understory herbs, Maianthemum canadense and Eurybia macrophylla, to experimental forest warming: early emergence is the key to enhanced reproductive output. American Journal of Botany 102: 1610-1624.

Jactel H, Koricheva J, Castagneyrol B. 2019. Responses of forest insect pests to climate change: not so simple. Current Opinion in Insect Science 35: 103-108.

Jump AS, Hunt JM, Peñuelas J. 2006. Rapid climate change-related growth decline at the southern range edge of Fagus sylvatica. Global Change Biology 12: 2163-2174.

Jump AS, Ruiz-Benito P, Greenwood S, Allen CD, Kitzberger T, Fensham R, Martínez-Vilalta J, Lloret F. 2017. Structural overshoot of tree growth with climate variability and the global spectrum of drought-induced forest dieback. Global Change Biology 23: 3742-3757.

Kaarlejärvi E, Baxter R, Hofgaard A, Hytteborn H, Khitun O, Molau U, Sjögersten S, Wookey P, Olofsson J. 2012. Effects of warming on shrub abundance and chemistry drive ecosystem-level changes in a forest-tundra ecotone. Ecosystems 15: 1219-1233.

Kennard DK, Matlaga D, Sharpe J, King C, Alonso-Rodriguez AM, Reed SC, Cavaleri MA, Wood TE. 2020. Tropical understory herbaceous community responds more strongly to hurricane disturbance than to experimental warming. Ecology and Evolution 10: 8906-8915.

Kovács B, Tinya F, Németh C, Ódor P. 2020. Unfolding the effects of different forestry treatments on microclimate in oak forests: results of a 4-yr experiment. Ecological Applications 30: e02043.

Kudo G, Ida TY. 2013. Early onset of spring increases the phenological mismatch between plants and pollinators. Ecology 94: 2311-2320.

Landuyt D, De Lombaerde E, Perring MP, Hertzog LR, Ampoorter E, Maes SL, De Frenne P, Ma S, Proesmans W, Blondeel $\mathrm{H}$ et al. 2019. The functional role of temperate forest understorey vegetation in a changing world. Global Change Biology 25: 3625-3641.

Lelli C, Bruun HH, Chiarucci A, Donati D, Frascaroli F, Fritz O, Goldberg I, Nascimbene J, Tottrup AP, Rahbek C et al. 2019. Biodiversity response to forest structure and management: comparing species richness, conservation relevant species and functional diversity as metrics in forest conservation. Forest Ecology and Management 432: 707-717.

Lembrechts JJ, Aalto J, Ashcroft MB, De Frenne P, Kopecký M, Lenoir J, Luoto M, Maclean IMD, Roupsard O, Fuentes-Lillo E et al. 2020. SoilTemp: a 
global database of near-surface temperature. Global Change Biology 26: 66166629 .

Lembrechts J, Lenoir J, Scheffers BR, De Frenne P. 2021. Designing countrywide and regional microclimate networks. Global Ecology and Biogeography 30: 1168-1174.

Lenoir J, Bertrand R, Comte L, Bourgeaud L, Hattab T, Murienne J, Grenouillet G. 2020. Species better track climate warming in the oceans than on land. Nature Ecology \& Evolution 4: 1044-1059.

Lenoir J, Gegout JC, Marquet PA, de Ruffray P, Brisse H. 2008. A significant upward shift in plant species optimum elevation during the $20^{\text {th }}$ century. Science 320: 1768-1771.

Lenoir J, Hattab T, Pierre G. 2017. Climatic microrefugia under anthropogenic climate change: implications for species redistribution. Ecography 40: 253-266.

Lenoir J, Svenning J-C. 2015. Climate-related range shifts - a global multidimensional synthesis and new research directions. Ecography 38: 15-28.

Lenth RV. 2021. EMMEANs: estimated marginal means, aka least-squares means. R package v.1.6.0. [WWW document] URL https://CRAN.R-project.org/ package $=$ emmeans.

Lesica P, Crone EE. 2017. Arctic and boreal plant species decline at their southern range limits in the Rocky Mountains. Ecology Letters 20: 166-174.

Lewis JD, Olszyk D, Tingey DT. 1999. Seasonal patterns of photosynthetic light response in Douglas-fir seedlings subjected to elevated atmospheric $\mathrm{CO}_{2}$ and temperature. Tree Physiology 19: 243-252.

Lüdecke D, Makowski D, Waggoner P, Patil I. 2020. Performance: assessment of regression models performance. [WWW document] URL https://easystats.github. io/performance/. doi: 10.5281/zenodo.3952174.

Ma S, Verheyen K, Props R, Wasof S, Vanhellemont M, Boeckx P, Boon N, De Frenne P. 2018. Plant and soil microbe responses to light, warming and nitrogen addition in a temperate forest. Functional Ecology 32: 1293-1303.

Maclean IMD, Duffy JP, Haesen S, Govaert S, De Frenne P, Vanneste T, Lenoir J, Lembrechts JJ, Rhodes MW, Van Meerbeek K. 2021. On the measurement of microclimate. Methods in Ecology and Evolution 12: 1397-1410.

Maes SL, Perring MP, Depauw L, Bernhardt-Römermann M, Blondeel H, Brūmelis G, Brunet J, Decocq G, den Ouden J, Govaert S et al. 2020. Plant functional trait response to environmental drivers across European temperate forest understorey communities. Plant Biology 22: 410-424.

Marialigeti S, Tinya F, Bidlo A, Odor P. 2016. Environmental drivers of the composition and diversity of the herb layer in mixed temperate forests in Hungary. Plant Ecology 217: 549-563.

Matlack GR. 1993. Microenvironment variation within and among forest edge sites in the eastern United States. Biological Conservation 66: 185-194.

Matlack GR. 2005. Slow plants in a fast forest: local dispersal as a predictor of species frequencies in a dynamic landscape. Journal of Ecology 93: 50-59.

Mölder A, Meyer P, Nagel R-V. 2019. Integrative management to sustain biodiversity and ecological continuity in Central European temperate oak (Quercus robur, Q. petraea) forests: an overview. Forest Ecology and Management 437: 324-339.

Moles AT, Perkins SE, Laffan SW, Flores-Moreno H, Awasthy M, Tindall ML, Sack L, Pitman A, Kattge J, Aarssen LW et al. 2014. Which is a better predictor of plant traits: temperature or precipitation? Journal of Vegetation Science 25: 1167-1180.

Neufeld H, Young D. 2014. Ecophysiology of the herbaceous layer in temperate deciduous forests. In: Gilliam FS, ed. The herbaceous layer in forests of Eastern North America. New York, NY, USA: Oxford University Press, 35-95.

Newton RJ, Hay FR, Ellis RH. 2020. Temporal patterns of seed germination in early spring-flowering temperate woodland geophytes are modified by warming. Annals of Botany 125: 1013-1023.

Olson DM, Dinerstein E, Wikramanayake ED, Burgess ND, Powell GVN, Underwood EC, D'amico JA, Itoua I, Strand HE, Morrison JC et al. 2001. Terrestrial ecoregions of the world: a new map of life on earth: a new global map of terrestrial ecoregions provides an innovative tool for conserving biodiversity. BioScience 51: 933-938.

Orczewska A, Glista A. 2005. Floristic analysis of the two woodland-meadow ecotones differing in orientation of the forest edge. Polish Journal of Ecology 53 : 365-382.

Orru M, Mattana E, Pritchard HW, Bacchetta G. 2012. Thermal thresholds as predictors of seed dormancy release and germination timing: altitude-related risks from climate warming for the wild grapevine Vitis vinifera subsp sylvestris. Annals of Botany 110: 1651-1660.

Palacio-Lopez K, Beckage B, Scheiner S, Molofsky J. 2015. The ubiquity of phenotypic plasticity in plants: a synthesis. Ecology and Evolution 5: 33893400.

Pérez-Harguindeguy N, Díaz S, Garnier E, Lavorel S, Poorter H, Jaureguiberry P, Bret-Harte MS, Cornwell WK, Craine JM, Gurvich DE et al. 2016.

Corrigendum to: new handbook for standardised measurement of plant functional traits worldwide. Australian Journal of Botany 64: 715-716.

Pigott CD. 1982. The experimental study of vegetation. New Phytologist 90 : 389-404.

Plue J, Van Gils B, De Schrijver A, Peppler-Lisbach C, Verheyen K, Hermy M. 2013. Forest herb layer response to long-term light deficit along a forest developmental series. Acta Oecologica-International Journal of Ecology 53: 63-72.

Poorter H, Niinemets Ü, Poorter L, Wright IJ, Villar R. 2009. Causes and consequences of variation in leaf mass per area (LMA): a meta-analysis. New Phytologist 182: 565-588.

R Development Core Team. 2020. $R$ : a language and environment for statistical computing, v.4.1.1. Vienna, Austria: R Foundation for Statistical Computing.

Richard B, Dupouey J-L, Corcket E, Alard D, Archaux F, Aubert M, Boulanger V, Gillet F, Langlois E, Macé $S$ et al. 2021. The climatic debt is growing in the understorey of temperate forests: stand characteristics matter. Global Ecology and Biogeography 30: 1474-1487.

Rothstein DE, Zak DR. 2001. Photosynthetic adaptation and acclimation to exploit seasonal periods of direct irradiance in three temperate, deciduous-forest herbs. Functional Ecology 15: 722-731.

Saunders SC, Chen J, Drummer TD, Crow TR. 1999. Modeling temperature gradients across edges over time in a managed landscape. Forest Ecology and Management 117: 17-31.

Scheffers BR, Phillips BL, Laurance WF, Sodhi NS, Diesmos A, Williams SE. 2013. Increasing arboreality with altitude: a novel biogeographic dimension. Proceedings of the Royal Society B: Biological Sciences 280: 20131581.

Schmidt M, Lischeid G, Nendel C. 2019. Microclimate and matter dynamics in transition zones of forest to arable land. Agricultural and Forest Meteorology268: 1-10.

Senf C, Seidl R. 2020. Mapping the forest disturbance regimes of Europe. Nature Sustainability 4: 63-70.

Smith TM, Smith RL. 2012. Plant adaptations to the environment. In: Elements of ecology. New York, NY, USA: Pearson Education, 116-144.

Sohn JA, Saha S, Bauhus J. 2016. Potential of forest thinning to mitigate drought stress: a meta-analysis. Forest Ecology and Management 380: 261-273.

Staude IR, Waller DM, Bernhardt-Römermann M, Bjorkman AD, Brunet J, De Frenne P, Hédl R, Jandt U, Lenoir J, Máliš F et al. 2020. Replacements of small- by large-ranged species scale up to diversity loss in Europe's temperate forest biome. Nature Ecology \& Evolution 4: 802-808.

Stott P. 2016. How climate change affects extreme weather events. Science 352: $1517-1518$.

Svenning JC, Normand S, Skov F. 2008. Postglacial dispersal limitation of widespread forest plant species in nemoral Europe. Ecography 31: 316-326.

Swanson ME, Franklin JF, Beschta RL, Crisafulli CM, DellaSala DA, Hutto RL, Lindenmayer DB, Swanson FJ. 2011. The forgotten stage of forest succession: early-successional ecosystems on forest sites. Frontiers in Ecology and the Environment 9: 117-125.

Taylor R, Pearcy R. 1976. Seasonal patterns of the $\mathrm{CO}_{2}$ exchange characteristics of understory plants from a deciduous forest. Canadian Journal of Botany 54 : 1094-1103.

Thers H, Bocher PK, Svenning JC. 2019. Using lidar to assess the development of structural diversity in forests undergoing passive rewilding in temperate Northern Europe. PeerJ 6: 20.

Thom D, Sommerfeld A, Sebald J, Hagge J, Muller J, Seidl R. 2020. Effects of disturbance patterns and deadwood on the microclimate in European beech forests. Agricultural and Forest Meteorology 291: 11.

Tinya F, Kovács B, Prättälä A, Farkas P, Aszalós R, Ódor P. 2019. Initial understory response to experimental silvicultural treatments in a temperate oakdominated forest. European Journal of Forest Research 138: 65-77.

Tinya F, Odor P. 2016. Congruence of the spatial pattern of light and understory vegetation in an old-growth, temperate mixed forest. Forest Ecology and Management 381: 84-92. 
Tsai H-C, Chiang J-M, McEwan RW, Lin T-C. 2018. Decadal effects of thinning on understory light environments and plant community structure in a subtropical forest. Ecosphere 9: e02464.

Valladares F, Laanisto L, Niinemets U, Zavala MA. 2016. Shedding light on shade: ecological perspectives of understorey plant life. Plant Ecology \& Diversity 9: 237-251.

Vangansbeke P, Máliš F, Hédl R, Chudomelová M, Vild O, Wulf M, Jahn U, Welk E, Rodríguez-Sánchez F, De Frenne P. 2021. ClimPlant: realized climatic niches of vascular plants in European forest understoreys. Global Ecology and Biogeography 30: 1183-1190.

Velásquez AC, Castroverde CDM, He SY. 2018. Plant-pathogen warfare under changing climate conditions. Current Biology 28: R619-R634.

Verheyen K, Honnay O, Motzkin G, Hermy M, Foster DR. 2003. Response of forest plant species to land-use change: a life-history trait-based approach. Journal of Ecology 91: 563-577.

Walck JL, Hidayati SN, Dixon KW, Thompson K, Poschlod P. 2011. Climate change and plant regeneration from seed. Global Change Biology 17: 21452161

Wasof S, Lenoir J, Gallet-Moron E, Jamoneau A, Brunet J, Cousins SAO, De Frenne P, Diekmann M, Hermy M, Kolb A et al. 2013. Ecological niche shifts of understorey plants along a latitudinal gradient of temperate forests in north-western Europe. Global Ecology and Biogeography 22: 1130-1140.

Westoby M. 1998. A leaf-height-seed (LHS) plant ecology strategy scheme. Plant and Soil 199: 213-227.

Westoby M, Wright IJ. 2006. Land-plant ecology on the basis of functional traits. Trends in Ecology \& Evolution 21: 261-268.

Whigham DE. 2004. Ecology of woodland herbs in temperate deciduous forests. Annual Review of Ecology Evolution and Systematics 35: 583-621.

Wild J, Kopecký M, Macek M, Šanda M, Jankovec J, Haase T. 2019. Climate at ecologically relevant scales: a new temperature and soil moisture logger for longterm microclimate measurement. Agricultural and Forest Meteorology 268: 40-47.

Willems FM, Scheepens JF, Ammer C, Block S, Bucharova A, Schall P, Sehrt M, Bossdorf O. 2021. Spring understory herbs flower later in intensively managed forests. Ecological Applications 31: e02332.

Williamson J, Slade EM, Luke SH, Swinfield T, Chung AYC, Coomes DA, Heroin H, Jucker T, Lewis OT, Vairappan CS et al. 2021. Riparian buffers act as microclimatic refugia in oil palm landscapes. Journal of Applied Ecology 58: 431-442.

Wolkovich EM, Cook BI, Allen JM, Crimmins TM, BetancourtJL, Travers SE, Pau S, RegetzJ, Davies TJ, Kraft NJB et al. 2012. Warming experiments underpredict plant phenological responses to climate change. Nature 485: 494-497.

Zellweger F, Coomes D, Lenoir J, Depauw L, Maes SL, Wulf M, Kirby KJ, Brunet J, Kopecký M, Máliš F et al. 2019. Seasonal drivers of understorey temperature buffering in temperate deciduous forests across Europe. Global Ecology and Biogeography 28: 1774-1786.

Zellweger F, De Frenne P, Lenoir J, Vangansbeke P, Verheyen K, BernhardtRömermann M, Baeten L, Hédl R, Berki I, Brunet J et al. 2020. Forest microclimate dynamics drive plant responses to warming. Science 368: 772 775 .

\section{Supporting Information}

Additional Supporting Information may be found online in the Supporting Information section at the end of the article.

Fig. S1 Maps of the distribution ranges of the 12 species included in the study.

Fig. S2 Violin plots of microclimatic variables grouped by region, forest structure and plot position.

Fig. S3 Violin plots of community level response variables grouped by region, forest structure and plot position.
Fig. S4 Pictures of the experimental setup.

Fig. S5 Violin plots of photosynthetically active radiation measurements and the effect of the light treatment.

Fig. S6 Violin plots of photosynthetically active radiation measurements and the effect of the forest structure.

Fig. S7 Violin plots of soil moisture and soil, surface and air temperature measurements and significance of the effect of the warming treatment, forest structure, interior vs edge position and region according to the linear mixed model.

Fig. S8 Volumetric soil moisture measured in control and warming treatments during the growing seasons of 2019 and 2020.

Fig. S9 Estimates and 95\% credible intervals for models for soil temperature measured by lascar loggers in all treatments.

Fig. S10 Violin plots of soil temperature measured by lascar loggers in all treatments and significant differences between treatments.

Fig. S11 Timeline of start and measurements during the experiment.

Fig. S12 Linear regressions of the species-specific plant height responses to the light treatment for simple and complex forest structures.

Fig. S13 Linear regressions of the species-specific plant height responses to the light treatment for different regions.

Fig. S14 Linear regressions of the species-specific plant height response to the warming treatment for different regions.

Fig. S15 Violin plots of community weighted means (CWM) specific leaf area (SLA), plant height and total cover and significance of the effect of the forest structure and region according to the linear mixed-effect models (LMMs).

Fig. S16 Violin plots of CWM SLA and total cover and significance of the effect of the interior vs edge position and region according to the LMMs.

Fig. S17 Estimates and 95\% credible intervals for species models for SLA, plant height and cover for the cold-adapted forest specialists.

Fig. S18 Estimates and 95\% credible intervals for species models for SLA, plant height and cover for the warm-adapted forest specialists.

Fig. S19 Estimates and 95\% credible intervals for species models for SLA, plant height and cover for the cold-adapted generalists. 
Fig. S20 Estimates and 95\% credible intervals for species models for SLA, plant height and cover for the warm-adapted generalists.

Fig. S21 Pearson correlations of the CWM SLA, plant height and total cover.

Fig. S22 Linear regressions of the species-specific responses to the warming treatment with the species' colonizing capacity index and thermal niche optimum.
Table S1 Site characteristics of the experimental locations.

Table S2 The percentage survival of the 12 species per region and per growing season.

Please note: Wiley Blackwell are not responsible for the content or functionality of any Supporting Information supplied by the authors. Any queries (other than missing material) should be directed to the New Phytologist Central Office. 